\title{
Human topographic signatures and derived geomorphic processes across landscapes
}

5

6

7

8

9

10

11

12

13

\author{
Paolo Tarolli*, Giulia Sofia \\ Department of Land, Environment, Agriculture and Forestry - University of Padova \\ Agripolis, viale dell'Università 16, Italy
}

Revised version resubmitted to Geomorphology

December 4, 2015

pages: 55

\footnotetext{
* Corresponding author. Tel: +39 (049) 8272677, fax: +39 (049) 8272686
}

e-mail address: paolo.tarolli@unipd.it (P. Tarolli) 


\section{Abstract}

The Earth's surface morphology, in an abiotic context, is a consequence of major forcings such as tectonic uplift, erosion, sediment transport, and climate. Recently, however, it has become essential for the geomorphological community to also take into account biota as a geomorphological agent that has a role in shaping the landscape, even if at a different scale and magnitude from that of geology. Although the modern literature is flourishing on the impacts of vegetation on geomorphic processes, the study of anthropogenic pressures on geomorphology is still in its early stages. Topography emerges as a result of natural driving forces, but some human activities (such as mining, agricultural practices and the construction of road networks) directly or indirectly move large quantities of soil, which leave clear topographic signatures embedded on the Earth's morphology. These signatures can cause drastic changes to the geomorphological organization of the landscape, with direct consequences on Earth surface processes. This review provides an overview of the recent literature on the role of humans as a geological agent in shaping the morphology of the landscape. We explore different contexts that are significantly characterized by anthropogenic topographic signatures: landscapes affected by mining activities, road networks and agricultural practices. We underline the main characteristics of those landscapes and the implications of human impacts on Earth surface processes. The final section considers future challenges wherein we explore recent novelties and trials in the concept of anthropogenic geomorphology. Herein, we focus on the role of high-resolution topographic and remote-sensing technologies. The reconstruction or identification of artificial or anthropogenic topographies provides a mechanism for quantifying anthropogenic changes to landscape systems. This study may allow an improved understanding and targeted mitigation of the processes driving geomorphic changes during anthropogenic development and help guide future research directions for development-based watershed studies. Human society is deeply affecting the environment with consequences on the landscape. Therefore, establishing improved management measures that consider the Earth's rapidly changing systems is fundamental. 
Keywords: geomorphology; anthropogenic signatures; Anthropocene; mining; roads; mountains; floodplains; remote sensing; high-resolution topography

\section{Introduction}

Landscapes are characterized by distinctive morphologies that are mainly caused by major forcings such as tectonic uplift, erosion, sediment transport, and climate that have shaped the Earth's surface and left characteristic topographic signatures. In addition to these processes, biota forcing might play a role in shaping the landscape, but, of course, at a different scale and magnitude than geological forcing. In biotic landscapes, vegetation through its roots influences soil formation and surface erosion. Biota also influence climate and, as a consequence, the mechanisms that control erosion rates and the evolution of the landscape. Dietrich and Perron (2006) compared the hypothetical frequency of occurrence of landform properties for the present Earth and an abiotic Earth. They suggested that the frequency distributions of measurable landform properties (such as mountain height, steepness, and curvature) could greatly differ, although all observed landform types would be found in both biotic and abiotic worlds (Fig. 1a). The question is, if we can suppose that there is evidence of biota forcing, what is the role of humans? Figure $1 \mathrm{~b}$ shows a real case study of the relative likelihoods that landform slopes will take a given value (probability density functions, pdfs) in a natural and a terraced landscape (the slope was calculated using high-resolution topography derived from LiDAR data). The result is interesting as their distributions seem to confirm the hypothesis of Dietrich and Perron (2006). Even if all slope values are found in the natural and in the anthropogenic environments, humans actively alter the frequency of occurrence of some specific slope values. In the case presented in Figure $1 b$, the natural morphology presents a bell-shaped distribution of slopes, with a peak around the average slope $\left(\sim 35^{\circ}\right)$. On the other hand, the anthropogenic slope pdf presents two peaks: one around the average value and one around low slope values. These two peaks are caused by the walls (having high values of slopes) and by the benches (low values of slopes) of the terraces.

Fig. 1 
Society developed significantly during the Holocene (from hunting-gathering, to farming, to complex societies and metropolises), and the increase in population was related to a progressive increase in intensive agriculture, raw material demand and urbanization. As a consequence, human activities are leaving a significant signature on the Earth by altering its morphology, processes, and ecosystems (Ellis, 2011). Anthropogenic landscapes cover as great an extent of the Earth's land surface as many other globally important ecosystems (Foley et al., 2005). In anthropogenic landscapes, human alteration is reflected by artificial Earth surface features (e.g., artificial channels, road networks, agricultural practices and mining activities) that may affect natural processes (Tarolli, 2014). Indeed, the scientific community is now debating the fact that we are living in a new geological epoch, the Anthropocene (Zalasiewicz et al., 2008, 2011a, 2011b, 2014; Monastersky, 2015), where human activities leave a significant, if not dominant, signature on the Earth. Whether this is true for the whole of mankind or for only some civilizations (Crist, 2013) and whether human bioturbation (Zalasiewicz et al., 2014) constitutes a negligible (Visconti, 2014) or substantial fraction of long-term Earth geological activities are still up for debate. Some authors have highlighted how human impacts are often difficult to separate from naturally driven activities (Fuller et al., 2015), and others have argued that it might be too soon to determine the human impact on geological records (Lewing and Macklin, 2014; Visconti, 2014; Smil, 2015). Aside from this recent ongoing debate, geomorphologists have long investigated the impacts of human societies on Earth surface processes and landform records, without needing the motivation of creating a new geological time interval (Brown et al., 2013).

\subsection{Humans as a geologic agent?}

Defining humans as a geologic agent might sound a little strange or even a provocation. Further, of course, if we compare human-induced changes to geologic forcing through the millennia, we are looking at a different scale and magnitude. However, humans have the potential to amplify geomorphic processes (Wolf et al., 2014). Bioturbation by humans ('anthroturbation') is a phenomenon without precedent in Earth history and is orders of magnitude greater in scale than 
any preceding nonhuman type of bioturbation (Zalasiewicz et al., 2014). Humans have become the dominant element in many Earth surface processes at different scales (Steffen et al., 2007; Wohl, 2013), to the point that human activities can be considered distinct from, but comparable to, the effects of climatic or tectonic transformations (Macklin et al., 2014). According to Wilkinson (2005), humans move increasingly large amounts of rock and sediment during various construction activities, and therefore become a geological agent. They modify the spatial distribution and rates of hydraulic and geomorphic processes (Fryirs and Brierley, 2012), which might result in land degradation, and geomorphic changes (Doolittle, 2006). Furthermore, anthropogenic transformations coupled with the natural system can cause geomorphological processes to continue in a 'genetically modified' form (Lewin, 2013), and the results of this combined forcing might be preserved in long-term geological records, at least in some environments (Brown et al., 2013; Jefferson et al., 2013).

Unlike natural geomorphic processes, the work done by humans is focused in specific locations with well-defined intent (Guthrie, 2015), and as a consequence, specific anthropogenic topographic signatures emerge. Looking at the different signatures of humans, we can mention mining activities, road networks and agricultural practices such as terracing and land reclamation. These signatures are very connected to current and future societal changes. In recent years, there has been a rising demand for base metals and industrial minerals, which is also connected to research into new forms of energy production (Vidal et al., 2013). Populations' needs for food will more than likely push the expansion of arable lands (D'Odorico and Rulli, 2011). Irrigated lands are also expected to expand (Foley et al., 2011). Terraced areas are greatly threatened by abandonment (Tarolli et al., 2014) or, on the other hand, by the intensification and specialization of agriculture (Cots-Folch et al., 2009). In addition, in the next few decades there may be a progressive increase in transportation networks (Sidle and Siegle, 2012).

These signatures can cause drastic changes to the geomorphic organization of the landscape, with direct consequences on Earth surface processes (e.g., Mossa and James, 2013; Sofia et al. 2014c; Tarolli et al., 2014, 2015). Thus, this review provides an overview of the recent challenging 
133 theme of the role of humans as a geological agent, specifically as connected to those elements 134 that leave a clear topographic signature on the Earth's surface. The goal is to present the state of 135 the science of the analysis of human bioturbation that can serve as a basis to improve 136 environmental planning, mitigate the consequences of anthropogenic alteration, and provide useful 137 guidelines in the future challenges section. Identifying signals connected to anthropogenic topographic signatures within Earth surface processes might help provide a better understanding

139 of current settings, the future and past steps in the evolution of our planet, and to schedule 140 appropriate environmental planning for sustainable development, to mitigate the consequences of anthropogenic alteration.

\section{Mining}

Recent rapid urbanization in developing countries is spurring the demand for industrial products and infrastructures such as electricity grids, transportation systems and buildings (Kobayashi et al., 2014). For developed countries, on the other hand, renewable energy requires infrastructures built with metals (Vidal et al., 2013). Therefore, more mining is almost unavoidable, and it is predicted that the demand for base metals in 2050 will be several times the current demand (Halada et al., 2008). Focusing on the quantities of mined minerals, Rogich and Matos (2008) highlighted that there has been a constant increase over the years in mineral extractions, mostly for construction materials. However, increases in mineral extraction are concomitant with increases in population, and the overall extraction per person in the 1980s was similar to that of the 2000 s despite the fact that the gross extraction has been increasing. Given these trends and the trends in our society, it is important to account for the fact that mining can have a significant impact on catchments, during mining and for many years after the cessation of mining (Hancock et al., 2008; Herrera et al., 2010), which can influence landscape evolution (Haigh, 1978; Martín-Duque et al., 2010), sediment 157 transfer (Macklin and Lewin, 1989) and thus geomorphology as a whole system (Mossa and 158 James, 2013). The most recent review about the impact of surface and underground mining on the 159 geomorphic system is by Mossa and James (2013). This section of the paper will focus specifically 
on surface mining, which leaves an obvious topographic signature on the landscape through the creation of large landforms (Fig. 2) and the addition of mine tailings.

Fig. 2

Table 1 collects the most significant literature on surface mining and connected geomorphic processes, and it focuses on four main issues: (i) surface mining and consequent erosion, (ii) mining-induced effects such as subsidence, (iii) landslide/debris-flow/rockfall risk, and (iv) effects on runoff. In the following sections, we will focus in detail on the most critical issues connected to these four points.

Tab. 1

\subsection{Mining and erosion}

Land displacement can be seen as a form of direct erosion on a global scale as the quantity of material mechanically moved within the mines (Fig. 3a). However, mining activities also produce erosion issues at local scales, when large quantities of sediment are transported by water erosion (Fig. 3b).

Fig. 3

The contribution of construction and mining activities to the excavation and displacement of solid materials on the Earth's surface is important. Quantifying such displacements is not obvious, but some works in the literature allow a first insight. However, the measurement units are not always homogeneous. To allow a comparison, for those works reporting the values of moved material in weight per person, in this section we consider (i) the world or country population at the time of the survey of each referenced work, (ii) the extent of the considered country, and (iii) we also considered that the affected volumes were uniformly distributed over the area analysed, and to account for an overall rate of erosion in $\mathrm{mm} \mathrm{y}^{-1}$ we assumed a bulk density of $2000 \mathrm{~kg} \mathrm{~m}^{-3}$ for construction/mining together. For those works reporting the values in weight at the plot or catchment scale, we assumed a bulk density of $1500 \mathrm{~kg} \mathrm{~m}^{-3}$. Hooke (2000) estimated that construction in the past required moving (importing or excavating) $5 \mathrm{~m}$ of stone with an average density of $2350 \mathrm{~kg} \mathrm{~m}^{-3}$ per square meter; we assumed a slightly lower value to account for mineral 
production and excavation (e.g., coal, gravel, sand). At the hillslope scale, mine soils commonly have higher bulk densities and lower porosities than native soils due to heavy traffic associated with grading (Thurman and Sencindiver, 1986), thus we assumed a higher value than that assumed by Montgomery (2007b) for soil erosion.

We are aware that these are a rough simplification of reality and that more information should be accounted for: however, the transformation of the published values in $\mathrm{mm} \mathrm{y}^{-1}$ allows for a direct comparison between the works. The final values should be considered to be only indicative rather than exact measurements.

In the past, large scale mining activities together with construction projects have been estimated to move approximately 20 t pers $^{-1} \mathrm{y}^{-1}$ in industrialised countries (Luttig, 1987). These numbers seem to have been confirmed, with an estimated rate of $\sim 16.8 \mathrm{t} \mathrm{pers}^{-1} \mathrm{y}^{-1}$ in the United States in the 1990s (Hooke, 1999) and $16.5 \mathrm{t} \mathrm{pers}^{-1} \mathrm{y}^{-1}$ in Britain (Douglas and Lawson, 2000). Other sources show a global rate of $\sim 9.3 \mathrm{t}_{\text {pers }}{ }^{-1} \mathrm{y}^{-1}$, with $\sim 15.7 \mathrm{t} \mathrm{pers}^{-1} \mathrm{y}^{-1}$ in Europe (Douglas and Lawson, 2000).

Soil erosion rates reported in various units in the literature and converted to equivalent lowering rates provide an interesting overview. We can estimate the rates of erosion connected to mines and/or construction activities, which range from $\sim 0.2-0.3 \mathrm{~mm} \mathrm{y}^{-1}$ (USA and industrialized countries in the 1980s) to $0.6 \mathrm{~mm} \mathrm{y}^{-1}$ in Europe, compared to a natural European erosion of $0.05 \mathrm{~mm} \mathrm{y}^{-1}$. The global estimated erosion rate was $\sim 0.4 \mathrm{~mm} \mathrm{y}^{-1}$. Among the industrialized countries, given the smaller extent of the area, the highest erosion rate apparently was for Britain $\left(\sim 2 \mathrm{~mm} \mathrm{y}^{-1}\right)$. Mining and construction are also responsible for erosion at the local-scale at the plot and catchment scales with watershed scale rates that range from $0.1 \mathrm{~mm} \mathrm{y}^{-1}$ to $3 \mathrm{~mm} \mathrm{y}^{-1}$ (Hancock et al., 2006; Rivas et al., 2006; Meng et al., 2012; Trabucchi et al., 2012). At the hillslope scale, erosion rates can reach >10 $\mathrm{mm} \mathrm{r}^{-1}$ (Esling and Drake, 1988; Biemelt et al., 2005). Clearly, local erosion rates are differently influenced by vegetation, rocks, soils, local slopes, and roughness, and by subsidence and restoration plans (Sanchez and Karl Wood, 1989; Nicolau 2002; Choi et al. 2008). 
213 The numbers obtained above, although subject to uncertainties, can be compared with different 214 estimates of material transfer by geomorphic agents reported in Montgomery (2007b) (Fig. 4).

Fig. 4

216 Keeping in mind that the highest geomorphological effectiveness can be achieved by events of moderate magnitudes that occur more frequently (Guthrie, 2015), estimates from the literature suggest that the direct or indirect displacement of sediments related to mining activities varies between $<0.1$ to $>10 \mathrm{~mm} \mathrm{y}^{-1}$. This is a relatively high contribution, and it is considerable if compared with sediment production from natural processes; these values, although at different spatial and temporal scales, are in line with those of steep, tectonically active topographies (Fig. 4).

\subsection{Surface mining and land subsidence}

Surface subsidence (Fig. 5) is recognized as a problem in most countries, particularly those with significant mining and other underground resource extraction industries (Whittaker and Reddish, 1989).

In surface mining, land subsidence is mainly induced by the lowering of the water table caused by groundwater withdrawal (Jambrik, 1995; Wolkersdorfer and Thiem, 1999; Panilas et al., 2008; Woldai et al., 2009), and the rates of withdrawal-induced subsidence have been estimated in some areas to reach $50 \mathrm{~mm} \mathrm{y}^{-1}$ (Kircher et al., 2003). Mine-related subsidence causes the permanent inundation of land, aggravates flooding, changes topographic gradients, can induce fault reactivation (Donnelly, 2009; Woldai et al., 2009) and has direct effects on the natural (Bell et al., 2000) and built (Wolkersdorfer and Thiem, 1999) environment. The significance of mining subsidence as a geomorphic agent is mainly due to its spatiotemporal scale. Considering the time scale, subsidence can occur simultaneously to the mining activities and long after the mines have been abandoned (Bell et al., 2000) or actively restored. It is usually said that mines are somehow 'living creatures' that constantly change, even when their productive life has come to an end, causing subsidence and slope instability phenomena (Herrera et al., 2010). Regarding the spatial 
scale, the extent of the subsidence area can range from nearly equal to many times the mining area, where aquifers are dewatered and undergo compaction (Dunrud, 1984). Modern surface mining operations usually have significant extents, and they can also influence relatively large portions of the terrain adjacent to the crest of the open pit or around the extraction areas. The vertical magnitude of the subsidence itself typically does not cause problems. However, it is the associated surface compressive and tensile strains, curvature, tilts, and horizontal displacements that are the cause of the worst damage to the natural environment, buildings, and infrastructure (Herrera et al., 2012). The location and extent of the mine as well as the mining techniques in respect to geometrical and geological factors, play a key role in ground subsidence (Herrera et al., 2010). However, the accumulation of those effects gives an additional qualification to mining as a geologic agent.

\subsection{Surface mining and landslides/debris-muddy flows/rockfall hazards}

Rockfalls and landslides (Fig. 6) in surface mining are among the most critical threats associated with the various types of geological instabilities and also induce risks near the mine (e.g., Johnes et al., 2000; and Fig. 6b). Some authors have argued that in the mining framework, human beings are an active factor contributing to disasters (Ramani, 1995); and with the scale of mining extending, landslide disasters on the Earth's surface will become increasingly serious (He et al., 2009).

Fig. 6

Three types of induced-processes can be considered: (i) landslides/debris/rockfalls within the mine itself, (ii) indirect landslides/debris/rockfall hazards exacerbated or induced by mining activities in the surrounding landscape, and (iii) further indirect hazards connected to the movements of the mobilized material in areas away from the mine itself.

Concerning direct hazards within mines, surface deformations and slope stability from mining activities have been approached from a modelling point of view because these issues are very important to the mining industry as potential sources of danger to people and equipment. For this 
267 type of event, stability analysis and comprehensive treatment methods together with geotechnical data, sliding causes, and characteristics about landslides should be gathered to prevent economic and life loss (Wei et al., 2008; Peila et al., 2011; Li et al., 2012). An interesting aspect from a geomorphological point of view is the effect of mining on landslide/debris/rockfall hazards within the mined catchments. The presence of mining/quarrying activities is apparently responsible for very low frequency, catastrophic events but also for frequent events that recur on a daily or weekly basis (Hearn, 1995) and events that are triggered by medium-intensity rainstorms (Baroni et al., 2000; Cortopassi et al., 2008). In some environments, mining activities have been proven to be the cause of the reactivation of dormant slides (Bentley and Siddle, 1996). Morphologies artificially modified by mining in conjunction with climate inputs (e.g., intense rainfall, Erginal et al., 2008) and geology (e.g., existing geological discontinuities, Laimer and Mulleger, 2012) have also been underlined as a crucial element that contributes to landslides.

In addition to landslide processes, mining can produce debris flows and muddy floodwaters from tailings failures, which results in floods (Fig. 7) that are commonly composed of water with high sediment concentrations (Guerrero et al., 2008; Rico et al., 2008a). These events generally occur in active mines and only rarely occur in abandoned ponds (Rico et al., 2008a, b).

Without denying the role of natural forcing, the frequency of induced events (daily or weekly basis) and triggering connected with medium magnitude climatic episodes or the exacerbation of events related to intense climatic episodes seem to indicate that anthropogenic pressure can indeed play

\subsection{Surface mining and runoff}

As in the case of subsidence and erosion, the effects of mining on runoff can continue once the extraction activities have stopped. It has been underlined how reclaimed surface-mines cause increased runoff more rapidly than undisturbed areas (Kilmartin, 1989; Negley and Eshleman, 
between the rainfall and flood peak, reduced groundwater recharge and higher sediment loads in the affected catchments. In addition, the destruction of interfluves connected to the removal of rocks below the water table can alter the natural groundwater flow paths, which can contribute to the overall increase in flow velocities and the shortening of flow paths (Holmes et al., 1993). Over large areas, surface mining can be correlated to increases in flood extent (Katpatal and Patil, 2010) and magnitude (Ferrari et al., 2009), with greater rates observed for less frequent return intervals (Ferrari et al., 2009). Interestingly, all the above findings seem to indicate that mining leaves the landscape in a condition more similar to urbanized areas than to natural reclaimed landscapes.

\section{Roads}

Among the anthropogenic modifications of landscapes, road construction has increased dramatically, and new surfaces have appeared in most areas of the world (Jimenez et al., 2013). Networks of roads interact with water and sediment flow paths in multiple ways (Wemple et al., 1996; Jones et al., 2000; Forman et al., 2003). Roads influence a variety of hydrologic and geomorphic processes, which has been well known for a long time (Reid and Dunne, 1984; Luce and Cundy, 1994; Montgomery, 1994; Luce and Wemple, 2001). Among the environmental effects of roads, the effects on water quality, aquatic ecology (Luce, 2002) and ecological processes (Jones et al., 2000; Coffin, 2007) are critical. Table 2 reports the most significant literature regarding roads and geomorphic processes in hilly/mountainous landscapes and issues related to runoff, sediment production, erosion, connectivity and geomorphic processes in flat landscapes.

\section{Tab. 2}

\subsection{Roads in mountainous / hilly landscapes}

Roads in mountainous/hilly landscapes support agricultural development, timber harvesting, local travel, trade and tourism, but at the same time they present difficult and pressing environmental challenges in many locations around the world (Petley et al., 2007; Sidle and Ziegler, 2012). Figure 8 shows an example of a rural mountain road in Nepal. Interestingly, in 2010 (Fig. 8b) the road 
suffered from a series of large landslides along its path. Google Earth also provided an image from 2008 (Fig. 8a), which was taken before the road was constructed. In that year, there were no landslides at the same location. It is clear that a landslide can result from the combination of a whole range of natural factors; in this case, however, human involvement is evident.

Fig. 8

\subsubsection{Roads, runoff, erosion and sediment production}

Roads, tracks and trails in mountainous/hilly landscapes collect runoff from overland flows (Fig. 9a) as well as from rain falling on road surfaces (Fig. 9b). As a consequence, they can produce runoff much more rapidly than the surrounding landscape.

Fig. 9

Roads and geomorphic processes on hillslopes interact in multiple ways: (i) roads lead to a decrease of infiltration due to the rerouted flow paths; thus, they lead to an increase in surface runoff (Wemple and Jones, 2003; Hölzel and Diekkrüger, 2012); (ii) road segments can intercept subsurface flows and reroute them to ditches and previously unchanneled hillslopes, thus increasing the potential for erosion (Wemple et al., 2001; Borga et al., 2004; Ziegler et al., 2004; Tarolli et al., 2013, 2015); (iii) roads act simultaneously to rainfall events; thus, erosion is controlled both by the road and by the rainfall characteristics (MacDonald et al., 2001; Wemple et al., 2001; Sudgen and Woods, 2007; van Meerveld et al., 2014); (iv) they enhance the effects of other forcings (e.g., vegetation removal) (Harr et al., 1975; Eisenbies et al., 2007); and (v) the relative position of the road with respect to the landscape, road slope and maintenance status have impacts on soil erosion (Sudgen and Woods, 2007; Bochet et al., 2010; Brown et al., 2013; Butzen et al., 2014).

As a consequence of the above interactions, roads can initiate debris slides that increase the rate of mass wasting (Swanson and Dyrness, 1975), and they affect hydrological processes and water pathways (Fig. 10a) (Luce, 2002), floods and debris flows (Jones et al., 2000). In addition, roads can function as both production (Sugden and Woods, 2007; Jordan-lopez et al., 2009) and depositional sites for sediments (Fig. 10b), contributing to basin-wide production (Dunne and 
Leopold, 1978; Reid and Dunne, 1984; Ziegler and Giambelluca, 1997; Fu et al., 2010; Collins et al., 2010).

\section{Figure 10}

Some authors have emphasized that despite predicted increases in sediment yields from road surfaces, annual sediment yields at the catchment scale appeared to be within natural levels (Fransen et al., 2001). Other authors have emphasized how the net effect of roads was an increase in basin-wide sediment production, highlighting the simultaneous importance of natural hydrologic factors (Wemple et al., 2001; Wemple and Jones, 2003). Scale, however, matters. Road effects on streams vary depending on the scale; low-order headwater streams can be heavily influenced by roads, whereas this effect might be masked in higher-order catchments (Thomaz et al., 2014). Additionally, in small channels, road crossings can produced deposition, width/depth changes and bed fining, whereas larger channels produce different effects (Marion et al., 2014).

As a form of erosion, gully initiation is also affected by roads. In this framework, roads can have a greater effect than vegetation or ground cover, for example (Muñoz-Robles et al., 2010). Gully incision can be significant below culverts and near road drains (Wemple et al., 1996; Nyssen et al. 2002; Takken et al., 2008), but it can also develop in locations away from the road itself (Nyssen et al., 2002; Jungerius et al., 2002). In fact, roads alter the thresholds for gullying erosion (MuñozRobles et al., 2010, Katz et al., 2014) and also induce the development of individual gullies and multi-branched gully systems at a watershed scale (Superson et al., 2014).

\subsubsection{Connectivity}

Due to the induced effects on runoff, flow paths, erosion and sediment transport, roads can have an overall effect on the catchment connectivity. We consider two main effects: direct connectivity through channels and gullies and diffuse connectivity via overland flow paths (Croke et al., 2005). The lack of maintenance of anthropogenic features tends towards higher stability and lower efficiency of morphological processes, connected with a sustained decrease in slope-channel coupling (Latocha, 2014). The road network geometry also plays a key role in connectivity 
375 (Pechenick et al., 2014). Independent of scale, the proximity of the road to the stream can be a 376 valuable driver that discriminates the channel conditions, and the shape of the network can create 377 physical connections to the streams through short overland flow paths and gullies (Pechenick et 378 al., 2014). Section 5.1.3 will further examine the connection between road networks and 379 connectivity.

\subsection{Roads in flat landscapes}

382 Especially in floodplains, roads can have a significant impact on natural flood patterns and their functions. In floodplains, road construction generally follows two approaches: 'resistance' and 'resilience' alignment (Vis et al., 2003). The first approach increases the elevation of the road to create a dyke that prevents flood water from over-flowing the structure. In the second approach, the resilience strategy, roads are developed both by increasing road elevations and the implementation of flow-through structures to allow floodwaters to permeate the road alignment (Vis et al., 2003). In both cases, the flood pathways, extent and duration will be changed by road development (Beevers et al., 2012), with possible effects on erosion as well (Fig. 11)

Regarding mountainous environments, the drainage system of roads in a floodplain can have large geomorphic effects. The resistance and the resilience approaches cause two main interactions with geomorphic processes in floodplains: (i) impacts due to bridges, culverts and roadside ditches and (ii) impacts where the road structures act as dams along channels, causing connections or disconnections with the floodplain (Blanton and Marcus, 2009; 2013) or altering the hydrological properties of the landscape (Trizzino, 2015).

398 tributaries (Florsheim et al., 2001). The use of designed flow-through structures maintains inundation patterns, but with increasing levels of road development more impacts are observed to 400 hydraulic components such as water levels, velocities, inundation durations and extents (Beevers 401 et al., 2012). Roads and roadside ditches can also contribute to increasing the drainage density of 
watersheds, with effects on floods (Buchanan et al., 2013; Douven and Buurman, 2013). Roadrelated sediment sources from culverts and road ditches can contribute to rivers and tributaries (Florsheim et al., 2001; Zajac et al., 2002), which make roads an efficient means of transport for pollutants (Buchanan et al., 2013). Road networks act as an anthropogenic 'barrier' for water and sediment fluxes across the landscape (Kumar et al., 2014). The presence of a road network can influence the size and duration of inundated areas during floods, fragmenting habitats and drying wetlands (Beevers et al., 2012). Channels near roads can be narrower and simpler in form, and they generally lack depositional elements such as bars and islands (Blanton and Marcus, 2013). Even if they have a localized direct impact on the overall floodplain hydraulics (Douven et al., 2012), small changes in flood dynamics may have large ecological impacts, especially if the cumulative impacts of more road developments are taken into account.

\section{Agriculture}

Civilizations in floodplains tend to expand rapidly, as long as agriculture in the fertile river valley bottoms allows populations to grow (Montgomery, 2007a). However, as villages expand into cities, the construction of canals, dikes, and earthworks for flood protection, irrigation and reclamation follows (Hooke, 2000). Agricultural activities, among other activities, can significantly alter the geomorphology of large territories over the course of thousands of years and from the use of various tillage methods (Gottschalk, 1945; Costa, 1975). Shifting human geography, especially associated with changes in farming and agricultural activities, is a main factor that drives major soil erosion processes (Boardman and Poesen, 2006), and as a consequence of the exploding world population, there has been an astonishing increase in the geomorphological effects of agriculture. Agricultural lands have been subjected to drastic shifts in land use, characterized by a high diversity of trajectories depending on the local conditions, regional context and external influences (Verburg et al., 2010). In many countries where the economy has shifted from mainly agricultural to industrial, agricultural lands have been reforested (Fig. 12a and b) and lost to urbanization in highly 
populated areas (Fig. 12c and d), but in other cases, agriculture has intensified (Fig. 12e and f) with changes in agricultural techniques and consequent changes in the drainage system.

Fig. 12

The interaction between agriculture and geomorphic processes is the result of a combination of factors ranging from small to large scales. At the local scale, tillage practices can influence runoff and erosion (Van Oost et al., 2006), and agriculture can induce structural degradation of the soil (Palmer and Smith, 2013), which results in increases in runoff and transport capacity. At the local and medium scales, terracing practices have a direct effect on processes (Tarolli et al., 2014; Arnáez et al., 2015). Moving to a larger scale, land abandonment (see Sect. 4.2) and land expansion in previously uncultivated lands (Dotterweich, 2013; Dotterweich et al., 2013; Merten and Minella, 2013) can induce or alter geomorphological processes. In addition, hydrologic alteration (Florsheim et al., 2011), which is also connected to the alteration of the drainage network for irrigation purposes, plays a key role in the overall system (See sect. 4.3). However, although it is well known that agricultural activities are directly relevant to watershed hydrology and geomorphology, the specific effects of artificial drainage as contributors to processes are not well understood (Schottler et al., 2014), but sometimes, their effects are critical (Sofia et al., 2014c) (Fig. 13).

Figure 13

The following two sections, therefore, will focus on the direct effects of agriculture on soil erosion, with a specific focus on land abandonment and the indirect effects connected to changes in drainage systems. Table 3 recalls review papers and specific scientific special issues, focusing on exemplary case studies in different parts of the world and specific cultivations that underline the deep connection between agriculture and surface processes.

Tab. 3

\subsection{Agriculture and soil erosion}


Recently, García-Ruiz et al. (2015) offered a detailed analysis of published data on soil erosion rates (in units of mass per area and time) under a large range of climatic conditions and land uses, taken from more than 4000 sites worldwide. Their results revealed a number of general features, including the significant effect of land use, with agricultural lands yielding the highest erosion rates. Similar to the work on mining (Sect. 2.1), the soil erosion rates reported in García-Ruiz et al., (2015) for agricultural landscapes were converted to equivalent lowering rates, assuming a soil bulk density of $1200 \mathrm{~kg} \mathrm{~m}^{-3}$, which provided an update to the ideas of Montgomery (2007b) (Figure 14).

\section{Figure 14}

The data from Montgomery (2007b) that were updated using the values of García-Ruiz et al., (2015) show how cultivated fields from different regions mostly erode at rates typical of alpine terrains. These numbers confirm what others have found; erosion rates from agriculture are among the highest rates found for land uses (García-Ruiz and Lana-Renault, 2011), and they can exceed the rates of most natural erosion processes (Massa et al., 2012). Compared to long-term natural events, however, one should consider that agricultural techniques produce this amount of sediments in shorter periods of time (Dotterweich et al., 2015). This difference in time scale can become a critical problem, especially considering that the natural production of soil is relatively slow and that soil might not be 'naturally' renewable on a societal time scale (Stockmann et al., 2014).

Erosion from agriculture also has indirect effects on river desiccation, groundwater depletion, water pollution, sedimentation, salinization and salt-water intrusion (Atapattu and Kodituwakku, 2009). In addition, agricultural erosion can deliver sediment to the drainage network (Borselli et al., 2008), and it can have consequences on the rates and magnitudes of floodplain sedimentation (Doolittle, 2006; Knox, 2006). Connected with soil erosion from agricultural lands, floods, especially muddy floods, are also of growing concern in Western Europe (Bielders et al., 2003; Boardman et al., 2003, 2006; O'Connell et al., 2007; Evrard et al., 2007; Heitz et al., 2009; Boardman, 2010; Boardman and Vandaele, 2010). 


\subsection{Land abandonment with special reference to the Mediterranean region}

483

484

485

486

487

Land abandonment has significant environmental consequences that are not equally relevant in all regions of the world. The most evident effects of farmland abandonment are shown in Mediterranean areas, especially in semi-arid environments, which are primarily affected by erosion, piping and gullying (García-Ruiz, 2010). Specifically on hillslopes, the generalized abandonment of agricultural terraces can favour surface runoff, erosion and soil sliding (Arnaez et al., 2011; GarcíaRuiz and Lana-Renault, 2011; García-Ruiz et al., 2013; Tarolli et al., 2014, 2015). Land abandonment in Mediterranean environments is expected to increase the overall net soil losses and total erosion and decrease sediment delivery ratios (Debolini et al., 2013). Aside from the direct negative consequences of land abandonment, the recolonization of natural vegetation can also result in a reduction in soil loss and the progressive improvement of soil characteristics (García-Ruiz and Lana-Renault, 2011). However, such evolution can also result in changing stream morphologies, especially narrowing and incision, and a decline in sedimentation levels in Mediterranean reservoirs (García-Ruiz and Lana-Renault, 2011).

\subsection{Drainage systems}

In many agricultural regions, more than $80 \%$ of the catchment basins may be drained by surface ditches and subsurface drain pipes (Blann et al., 2009). Among the environmental impacts caused by agricultural drainage, we can mention habitat loss or alteration, reduced water quality and hydrologic alterations (Blann et al., 2009). Regarding hydrologic alterations, a coarsening of the drainage networks in floodplains might result in significant changes to total groundwater recharge (Krause et al., 2007) as well as changes in the connectivity of the watersheds, which can alter overland flows and create excess water hazards (Kiss and Benyhe, 2015). As a result, the presence of a specific drainage system may also limit the extent to which land cover would ever resemble historic hydrological conditions (Schilling et al., 2008). Connected to the coarsening of drainage networks, the loss of ditches might also result in an exacerbated flood risk (O'Connell et 
al., 2007, Wheater and Evans, 2009; Sofia et al., 2014c). This latter effect might be greater for events with shorter return times, with an increase in flood risk for rather frequent rainfall events that are not necessarily associated with extreme meteorological conditions and that are not necessarily associated with worst case scenarios (Sofia et al., 2014c). Furthermore, flows from artificial drainage networks affect stream baseflows and streamflow recession characteristics (Schilling and Helmers, 2008), and they have the potential to alter water budgets on a watershed scale (Schottler et al., 2014). Reduced surface storage and increases in conveyance can also result in increased flows in streams and rivers (Blann et al., 2009), with consequences on sediment transport capacities and increases in the amount of sediments carried downstream (Lenhart et al., 2012). These effects can be so prominent that in some environments, they exceed the effects of precipitation (Sofia et al., 2014c) and land-use changes (Schottler et al., 2014).

\section{Future challenges}

\subsection{Remote Sensing (RS) and High-resolution topography (HRT)}

Remote Sensing and Digital Elevation Models (DEMs) have been used in geomorphology for decades. Researchers in applied geomorphology and geomorphologic surveying and mapping have always relied upon these techniques. However, over the past decade, developments in technology have enabled the general public to be increasingly engaged with technology (Goodchild et al., 2012). Governments and remote-sensing communities inside and outside the scientific world are now seizing opportunities for sharing spatial data (Bernard et al., 2005; Krishnan et al., 2011; Wulder and Coops, 2014), and science-intensive firms are involved with 'open data' initiatives (Perkmann and Schildt, 2014). At the same time, due to the ease of processing and obtaining data,

a large amount of interest has arisen in obtaining high-resolution DEMs using flexible and 531 affordable technologies. The recent development of the Structure-From-Motion (SfM) photogrammetric technique (Westoby et al., 2012) and its application on UAVs (Martin-Vide, 2004;

533 Chen et al., 2015; Francioni et al., 2015) and even smartphones (Micheletti et al., 2015; 534 Prosdocimi et al., 2015) has opened new frontiers for the analysis of Earth surface processes and, 
in particular, anthropogenic processes. Unlike natural geomorphic processes, the work done by humans is focused on specific locations with well-defined intent (Guthrie, 2015). The resulting topographic signatures can be actively modelled only with the global availability of fine-scale, three-dimensional topographies, and today this framework offers a large advantage in terms of spatiotemporal coverage. In this context, the future challenge is the ability to actually model anthropogenic morphologies, quantify them, and analyse the links between anthropogenic elements and geomorphic processes. In addition, the involvement of public authorities, land managers and common users in the creation and dissemination of datasets might slowly allow the transfer the knowledge of geomorphic processes from the scientific to the practical world.

Tarolli (2014) and Passalacqua et al. (2015) proposed an overview of how HRT can be useful in engineered landscapes and offered a review of the most important works carried out in this field by researchers. In addition to the literature provided in the previously mentioned reviews, Table 4 reports the most recent and interesting works that address HRT and anthropogenic environments.

\section{Tab. 4}

In the following sub-chapters, three examples will be provided regarding how HRT can be useful for the analysis of anthropogenic geomorphologies. The case studies are based on the Slope Local Length of Auto-Correlation (SLLAC) proposed by (Sofia et al., 2014b) and successfully applied in mining landscapes in (Chen et al., 2015) (Chapt. 5.2.1), and in a slightly modified version of the procedure and the technique proposed in (Sofia et al., 2015), to automatically detect anthropogenic areas (Chapt. 5.2). A further example will show the connection between roads and geomorphic processes, which is based on the analysis of the sediment Connectivity Index proposed in Borselli et al., (2008) and Cavalli et al., (2013) on the changes to flow paths induced by roads, measured according to the Relative Path Impact Index (RPII) proposed by (Tarolli et al., 2013).

The original SLLAC metric (Sofia et al., 2014b) is based on a 2D cross-correlation between a slope patch and its surrounding areas. From this cross-correlation, it is possible to derive the correlation length as the horizontal distance of the areal cross-correlation that corresponds to $37 \%$ of the correlation maximum value. A second parameter, the Surface Peak Curvature $(S p c)$, is the 
average of the principal curvature of the local maximums on the SLLAC map, where each maximum is defined as a pixel higher than its 8 nearest neighbours. The Spc is statistically able to differentiate a terraced area from a natural one; $S p c$ increases as the landscape becomes more natural. Chen et al. (2015) furthermore proposed a polynomial (for mining landscapes) that related the value of the $S p c$ to the percentage of the terraced area within an analysed site. The connectivity index by Borselli et al., (2008) and Cavalli et al., (2013) is intended to represent the potential connectivity between different parts of the catchment and aims, in particular, at evaluating the potential connection between hillslopes and features, which act as targets or sources for transported sediment. The RPII instead considers the contributing area as a proxy of the flow path distributions, and in a logarithmic form emphasizes areas where the flows are increased due to the presence of anthropogenic features (Tarolli et al., 2013). See Sofia et al., (2014b), Chen et al., (2015), Sofia et al. (2015) for a full description of the cross-correlation computation and for the measure of the correlation length, Borselli et al., (2008) and Cavalli et al., (2013) for a full description of the Connectivity Index and Tarolli et al., $(2013,2015)$ for a clear description of the RPII.

\subsubsection{HRT for a quick comparison among different areas}

The purpose of the following example is to show the benefit of the availability of free HRT data (in this case LiDAR) to allow a rapid automatic comparison between areas that have different human pressures to associate them with study areas in different parts of the world.

Figure 15 shows the Bingham Canyon Mine (A) (UT, USA) and the Hull-Rust-Mahoning Mine (B) (MN, USA).

\section{Fig. 15}

The Bingham Canyon mine ( $\mathrm{A}$ in Fig. 15, Fig. 15a) is one of the largest man-made excavations in the world (Pankow et al., 2013) and has an open pit that is $0.97 \mathrm{~km}$ deep and $4 \mathrm{~km}$ wide. In 2013, the mine experienced a massive landslide that moved $\sim 65$ million cubic metres of material; this cumulative event was probably the largest non-volcanic landslide in North America in modern 
times (Pankow et al., 2013). For this area, the Utah Automated Geographic Reference Center offers a free download of a 2 m DTM collected in 2006 (AGRC, 2015) (Fig. 15b).

The Hull-Rust-Mahoning Mine (B in Fig. 15, Fig. 15d) is one of the widest open pit iron mines in the world; the mine has a 2.5 by $\sim 6 \mathrm{~km}$ footprint and a depth up to $\sim 180 \mathrm{~m}$. For this area, the Minnesota Geospatial Information Office of the Minnesota Department of Natural Resources offers a free download of a $1 \mathrm{~m}$ LiDAR DTM, which has an accuracy of $0.6 \mathrm{~m}$ (Minnesota Department of Natural Resources, 2015). To ensure homogeneity with the other study site, we generated a reduced-resolution ( $2 \mathrm{~m} \times 2 \mathrm{~m}$ per pixel) version of the Minnesota DTM, where each output cell contained the mean of the input cells that were encompassed by the extent of that cell (Fig. 15e). For the two areas, a SLLAC map was derived (Sofia et al., 2014b) (Fig. 15c, 15f).

It is clear that the open pit areas leave a deep signature on the topography that is captured by long fibres in the SLLAC map and high values of the correlation lengths, which underlines what Chen et al. (2015) found for open-pit mines in China. For the Bingham Canyon mine map, the Spc value is $4.4 \times 10^{-2} \mathrm{~m}^{-1}$, whereas for the Hull-Rust-Mahoning mine, it is $3.9 \times 10^{-2} \mathrm{~m}^{-1}$. These values are statistically similar to $S p c$ values of areas with greater than $10 \%$ terrace coverage in Chen et al. (2015) $(p-$ value $=0.2$ and 0.8 , respectively in a Mann-Whitney test, thus indicating a failure to reject the null hypothesis that the samples come from different populations).

According to the polynomial approach in Chen et al. (2015), the Bingham Canyon mine Spc corresponds roughly to $21 \%$ of terrace coverage within the site. The considered DTM is approximately $103 \mathrm{~km}^{2}$; thus, the estimate extent of the anthropogenic surface is approximately 22 $\mathrm{km}^{2}$. By roughly measuring the extent of the entire mine (not just the open pit), the mine covers approximately $30 \mathrm{~km}^{2}$. Therefore, the automatic procedure produced an estimate that is approximately $70 \%$ of the actual mine extent. However, by considering the confidence bounds of the Chen et al. (2015) relationship, the actual extent of the mine falls within these bounds. For the Hull-Rust-Mahoning mine, the Spc corresponds to $60 \%$ of the anthropogenic surface, approximately $240 \mathrm{~km}^{2}$, considering the extent of the analysed DTM. A rough estimate by hand of the extent of the mine, including the areas covered by water, is approximately $110 \mathrm{~km}^{2}$. If we 
616 include the footprints of the towns in the study area in the definition of the anthropogenic surface 617 (Hibbing, Keewatin and Chisholm), considering that buildings on LiDAR DTMs leave a clear mark 618 that is captured by the SLLAC (see Fig. 15f), as also underlined by Chen et al. (2015), we 619 measured an actual extent of approximately $250 \mathrm{~km}^{2}$, which is very close to the estimated area.

620 In the Hull-Rust-Mahoning Mine case study, it is interesting to see that the mine area itself presents numerous ponds. Clearly, on the LiDAR data these appear as a completely flat surfaces.

622 The SLLAC is based on the normalized cross correlation (Sofia et al., 2014b), and this measure is 623 an undefined operation in regions where there is zero variance within the analysed area. This is exactly the case for completely flat surfaces derived from water bodies on LiDAR DTMs. A road or

a flat field would not be the same as a water body because their surfaces have some roughness and, as a consequence, all the water bodies can be automatically identified as 'empty' spaces on the SLLAC maps.

\subsubsection{Track/monitor changes over time}

Anthropogenic changes follow economic and societal changes and thus occur rather quickly on a geological time scale. The availability of multi-temporal HRT surveys with short revisiting times offers an opportunity to effectively track those changes.

The SLLAC (Sofia et al., 2014b) is based on the spatial organization of slopes rather than absolute values and can therefore be applied to different topographic supports. As a matter of fact, this technique can potentially be generalized for application to any type of imagery. If we broaden the concept of slope, it is mathematically possible to compute the 'slope' (or gradient) of a greyscale image as the directional change in the intensity or colours (Eq. 1):

$$
\nabla f=\frac{\partial f}{\partial x} \hat{x}+\frac{\partial f}{\partial y} \hat{y}
$$

where $\frac{\partial f}{\partial x} \hat{x}$ and $\frac{\partial f}{\partial y} \hat{y}$ are the gradient in the $\mathrm{x}$ and $\mathrm{y}$ direction, respectively, and $f$ is the colour intensity in a greyscale range. Having the image gradient map, it is then possible to feed this input to the cross-correlation evaluation, thus deriving a Gradient Local Length of Auto-Correlation 
641 (GLLAC). The following example (Fig. 16) shows a mining area in Spain. For this area, aerial 642 photographs at $2 \mathrm{~m}$ resolution are available for 2005 (a) and 2008 (e).

643

644

645

646

647

648

649

650

651

652

653

654

655

656

657

658

659

660

661

662

663

664

665

666

667

Fig. 16

From these images, we computed the gradient (b) and (f), and we derived the GLLAC (c) and (g), considering the same parameters presented in Sofia et al. (2014b).

Once the GLLAC was derived, we computed the $S p c$ and the average GLLAC using a moving window of 1 ha, and we clustered the area into two parts. According to Sofia et al. (2015), the cluster with the lower Spc or, alternatively, the higher average SLLAC, can be considered as potentially anthropogenic; thus, we considered the same approach (Fig. 16d and h).

Despite limitations due to image illumination/sun exposure that might prevent some elements from being clear on the image, the GLLAC, analogously to the SLLAC, well captured the presence of terraces within the open pit mine and the presence of roads with elongated fibres. Comparing the two maps at two different times, it is possible to detect changes within the study sites and identify, for example, the expanded area of the mine. The area has an $S p c$ of $2.08 \times 10^{-2}$ in 2005 and 2.17 $\times 10^{-2}$ in 2008. Despite coming from a different source (GLLAC instead of SLLAC), the two values are statistically similar to the population of the Spc values of areas with more than $10 \%$ terrace coverage in Chen et al. (2015) ( $p$-value $=0.6$ and 0.5 , respectively, in a Mann-Whitney test, which indicates a failure to reject the null hypothesis that the samples came from different populations).

As in the previous example, using these values and considering the Chen et al. (2015) relationship, we obtained a $17 \%$ coverage by anthropogenic structures in 2005 vs. $33 \%$ in 2008 , which is a gain of $\sim 16 \%$ in structures over the complete extent of the considered image. In this case, the image covered approximately $1 \mathrm{~km}^{2}$, therefore the estimated change in the areas over time was approximately $16 \mathrm{~km}^{2}$. Clearly, the results may have been biased by the image quality and exposure to light, and the capability of tracking anthropogenic structures depends on their visibility on the map (e.g., this would not be possible under vegetation cover). The detection of anthropogenic signatures from a DEM has some confidence bounds (e.g., 10\% of terraced areas, 
according to Sofia et al. $2014 \mathrm{~b}$ or $\sim 4 \mathrm{~km} / \mathrm{km}^{2}$ of roads in Sofia et al., 2015). However, the SLLAC (and GLLAC) derived values, when considering natural or anthropogenic areas, are significantly different, and to our knowledge, there is no other indicator currently in the literature that is able to automatically relate human signatures to specific morphological characteristics. Thus, the flexibility of this image-based approach is promising.

\subsubsection{Understanding the link between processes and anthropogenic elements}

HRT describes the landscape topography, which is both a product and a driver of the activity of geomorphic processes. In the same way, the connectivity of landscape units with respect to water and sediment fluxes can be seen as both a driver and an emergent property of hydrological (Ali et al., 2014) and geomorphic processes. Road networks have a large effect both on sediment production and sediment delivery (see Chapt. 3); thus, the availability of HRT can help and provide a better understanding of road-related issues. The site chosen for this application was the Lookout Creek watershed within the Andrew Experimental Forest (OR, USA). In this area, numerous studies have underlined the relationship between roads and erosion (landslides and debris flows) (Swanson and Dyrness, 1975; Wemple et al., 1996; Jones et al., 2000; Wemple et al., 2001). For this site, the Experimental Forest website offers a free download of a LiDAR DTM at $1 \mathrm{~m}$ resolution in addition to a complete database of the slides and road network (Fig. 17a). The watershed is completely covered by vegetation; thus, the road network can be visible only by having either the actual locations of the roads or LiDAR datasets that capture the morphology under the forest cover.

Fig. 17

For this study, the Connectivity Index (Cavalli et al., 2013) was evaluated in terms of the (i) sediment delivery across the entire drainage system (as in the potential connection of the sediment between the hillslopes and catchment outlet) (Fig. 17a, 17b, 17h) and the sediment couplingdecoupling between the hillslopes, (ii) main channels (Fig. 17c, 17f and 17i) and (iii) the road network (Fig. $17 \mathrm{~d}, 17 \mathrm{~g}$ and $17 \mathrm{l})$. The choice of modelling these aspects results from the need to 
address some primary sediment management issues: (i) what is the probability that sediment from a certain sediment source (in this case, landslide processes) will reach the catchment outlet?; (ii) what is the probability that sediment eroded from the hillslopes will influence the drainage network?; and (iii) what is the probability that a specific event will deliver sediment to the road network.

There is no reference theory for the partitioning of the connectivity index into classes, and we therefore adopted a relative classification into four classes (High, Medium-High, Medium-Low and Low) by identifying break points that best grouped similar values and maximized the differences between classes (natural breaks); this has been found to be suitable for alpine watersheds, where the variability in the index ranges from -8 to 2 (Cavalli et al., 2013). In our study case, the connectivity value assumed similar ranges, therefore we deemed the same classification to be suitable.

For this watershed, Wemple et al. (2001) underlined how the roads influenced the overall sediment production in two ways: by producing sediments below the roads and by capturing sediments coming from above the road and delivering them downstream. We therefore selected two case studies: one where the landslides were located in the proximity of a road, but in the downstream direction (Fig. 17e, 17f, 17g), and one where the landslides were located above the roads (Fig. 17h, 17i, 17l). In both cases, the roads were built before the landslide events. In the first example, the slides occurred from 1964-1972, but the two roads within the area were built in 1959. In the second example, the landslide occurred in 1953, but the road was built in 1952.

In the first example, the analysed slides clearly did not deliver sediment to the road (Fig. 17g). By analysing the connectivity to the outlet (Fig. 17e) and to the network (Fig. 17f) it is possible to understand that the sediment produced by the slides nevertheless could have contributed to the total sediment of the watershed at the outlet. In the second example (Fig. 17h, 17i and 17l), the slide was produced above the road, and it had a high topographic connectivity to the road itself (Fig. 17l), but it was disconnected from the network because the road itself served as an obstacle, or buffer (Fryirs, 2013) (Fig. 17i). However, the connectivity to the road contributed to the overall 
connectivity of the sediment to the outlet (Fig. 17h) because the road itself deviated the flows downstream, thus increasing the probability of delivering the sediment to the watershed outlet. The analysis of the RPII (Fig. 18) for the two above examples gives further interesting insights.

Fig. 18

In the first case (Fig. 18a), the high value of the RPII $(>1 \sigma)$ indicates that the two landslides (white arrows in Fig. 18a) were probably induced by the presence of the road network. However, it is interesting to see that the deviation of the flows did not start on the road in the immediate proximity of the slides, but on another uphill section of the road network (third white arrow in Fig. 18a).

In the second example (Fig. 18b), the RPII enabled an understanding that the connectivity of the sediment to the outlet (Fig. 17h) was created by the road itself (Fig. 18b). Without the road network, this connectivity would probably not have existed.

The use of the Connectivity Index and RPII on both examples highlights what was found for the same watershed by Wemple et al. (2001) after an extensive field survey and using empirical data. Those authors argued that during extreme events, (i) the roads in the mid-slope positions dominated the production and redistribution of sediment (as underlined by the HRT analyses in Fig. 17e, 17f, 17g and Fig. 18a) and that (ii) a road network may have major impacts on stream channels far removed from the initiation sites (as underlined by HRT analyses in Fig. 17h, 17i, 17l and Fig. 18b). Therefore, in the context of anthropogenic geomorphologies, the use of HRT for the analysis of connectivity and road-induced changes in flows can provide a tool to better address the possible outcomes of sediment production, for example, and the impacts on the watershed in terms of how sediments can be delivered and transported within it. In addition, it would enable an understanding of where engineering efforts should be focused.

\subsection{Land planning and management as a function of induced Earth surface processes}

According to the latest State of World Population 2014 report from the UN, the global population is predicted to reach nearly 11 billion by 2100 . The increase in population and the introduction of new technologies will be inevitably linked to an increase in raw-material demand (e.g., the global 
production of concrete, steel, aluminium, copper and glass) (Vidal et al., 2013). In addition, if food production must keep pace with the demands of an ever-expanding global population, arable lands are expected to expand, with the expansion in developing countries being offset by a decline in the developed countries. Lands equipped for irrigation and harvested irrigated lands are also expected to expand (Alexandratos and Bruinsma, 2012). On the other hand, the results of recent studies suggest that there will likely be significant levels of farmland abandonment in Europe over the next 20-30 years (Renwick et al., 2013). In addition, in the next few decades, there may also be an increase in transportation networks in support of agricultural development, local travel, trade and tourism (Sidle and Ziegler, 2012). The result will be an increase in anthropogenic forcing with direct consequences on Earth surface processes, especially soil erosion, runoff, hazards and land degradation. A future challenge is to change the perspective of land planning and management: anthropogenic changes in landscapes (mining, agricultural activities and land-use changes) should be controlled and managed as a function of the induced geomorphic processes. Transportation networks need to be better planned and constructed with due attention to minimizing erosion and landslides, so that downstream communities and river systems are adequately protected (Sidle and Ziegler, 2012). In addition, agricultural policy potentially plays a key role in determining whether land is utilized for agriculture (Renwick et al., 2013). The same applies for cities. Cities need to be designed and planned with regard to potential runoff, water storage capacity and soil erosion due to the demand on raw and construction materials. The construction of new mining areas and the conversion of existing ones should consider the overall effects on the landscape, keeping in mind that a reclaimed mined area may never function like a natural one, but rather in a condition that is more similar to urbanized areas. Additionally, the rates of erosion that are induced by mining and agricultural activities, despite being on a shorter time scale than natural erosion rates, may become a critical problem considering that the natural production of soil is relatively slow and that soil might not be 'naturally' renewable on a societal time scale. Correct land management involving the scientific and land-management worlds is, in principle, an appropriate device to underpin this. Science can inform land-managers by providing evidence-based means for 
assessing the rates and scales of erosion and can assist land users and policy makers in devising appropriate and effective management techniques and systems. Although natural constraints cannot be influenced but can only be compensated for, degradation processes can sometimes be reversed through technical interventions and research innovations, and the Earth science community will absolutely play a key role in this.

\section{Final Remarks}

Natural processes can leave characteristic topographic signatures on the Earth's surface. Abiotic forcing (e.g., climate and tectonics) have played and will continue to play a significant role across larger time scales in shaping the landscape. However, biota forcing can also affect geomorphic processes. Vegetation, through its roots, influences soil formation and surface erosion. Biota also affect climate, and as a consequence, the mechanisms and erosion rates that control the evolution of the landscape. Humans are part of the biota as well. More than vegetation, human activities are leaving a significant signature on the Earth by altering its morphology, processes and ecosystems. We are looking at a different magnitude and scale with respect to abiotic forcing, however the resulting topographic signatures and related consequences are significant. Humans are able to move large amounts of materials during various construction activities (e.g., urban expansion and raw material demand) and thus play a similar role as a geologic agent. The population of the Earth is increasing; the last estimate debates the fact that we will reach 11 billion people by the end of this century if fertility rates do not drop. The consequences of this will result in an increase in urbanization processes, road networks, mining activities due to demands in raw materials in support of different needs (e.g., houses, smartphones, tablets and cars) and agriculture. At the end of this century, anthropogenic geomorphology probably will cover a large part of the Earth, with direct consequences to Earth surface processes, first to geomorphology but also to climate. Society, from a geomorphological point of view, should find solutions to minimize the following consequences: soil erosion and landsliding related to surface water flow interception by roads, soil 
802 erosion and mass movements related to mining activities, runoff and soil erosion related to land 803 use changes and issues related to anthropogenic drainage systems. The new remote sensing 804 technologies (e.g., LiDAR and low cost photogrammetric techniques) and the derived high805 resolution topography can greatly assist in the understanding of anthropogenic signatures and their 806 effects on processes. Society also needs to change its vision regarding land use planning and 807 management to find sustainable solutions. Road networks and urban expansion should be 808 controlled and managed as a function of the induced potential for erosion and floods. These will 809 probably be the great challenges of this century.

810 


\section{Acknowledgements}

812 The LiDAR data in Fig. $1 \mathrm{~b}$ were provided by the Italian Ministry for Environment, Land and Sea 813 (Ministero dell'Ambiente e della Tutela del Territorio e del Mare, MATTM) as part of the PST-A 814 framework. Data for the example reported in Chapt. 5.1.1. were provided by the Utah Automated 815 Geographic Reference Center (AGRC) and MnTOPO® (funding was provided by the Clean Water 816 Fund of the Clean Water, Land and Legacy Amendment). The data considered in the example in 817 Chapt. 5.2.3. for the Lookout Creek watershed were provided by the HJ Andrews Experimental 818 Forest research program, which is funded by the National Science Foundation's Long-Term 819 Ecological Research Program (DEB 08-23380), US Forest Service Pacific Northwest Research 820 Station and Oregon State University. The author especially wishes to thank the Editor and four 821 reviewers for the useful suggestions raised during the review stage.

822 


\section{References}

Agency, U.S.E.P., 1972. Erosion of tailings piles at consolidated copper co.'s mine, 07/1972 [WWW Document]. DOCUMERICA Environ. Prot. Agency's Progr. to Photogr. Doc. Subj. Environ. Concern, Compil. 1972 - 1977 (ARC identifier 542493). URL http://research.archives.gov/description/544064 (accessed 1.27.15).

AGRC, 2015. Utah Automated Geographic Reference Center [WWW Document]. 2 M. LiDARElev. Data. URL http://gis.utah.gov/about/data-policies/ (accessed 10.7.15).

Alexandratos, N., Bruinsma, J., 2012. World agriculture towards 2030/2050: the 2012 revision, ESA Working paper N. 12-03. Rome.

Ali, G., Birkel, C., Tetzlaff, D., Soulsby, C., McDonnell, J.J., Tarolli, P., 2014. A comparison of wetness indices for the prediction of connected saturated areas under contrasted conditions. Earth Surface Processes and Landforms 39, 399-413. doi:10.1002/esp.3506.

Arnáez, J., Lasanta, T., Errea, M.P., Ortigosa, L., 2011. Land abandonment, landscape evolution, and soil erosion in a Spanish Mediterranean mountain region: The case of Camero Viejo. L. Degrad. Dev. 22, 537-550. doi:10.1002/ldr.1032

Arnáez, J., Lana-Renault, N., Lasanta, T., Ruiz-Flaño, P., Castroviejo, J., 2015. Effects of farming terraces on hydrological and geomorphological processes. A review. Catena 128, 122-134. doi:10.1016/j.catena.2015.01.021

Atapattu, S.S., Kodituwakku, D.C., 2009. Agriculture in South Asia and its implications on downstream health and sustainability: A review. Agric. Water Manag. 96, 361-373. doi:10.1016/j.agwat.2008.09.028

Baroni, C., Bruschi, G., Ribolini, A., 2000. Human-induced hazardous debris flows in Carrara marble basins (Tuscany, Italy). Earth Surf. Process. Landforms 25, 93-103. doi:10.1002/(SICI)1096-9837(200001)25:1<93::AID-ESP53>3.0.CO;2-0

Beevers, L., Douven, W., Lazuardi, H., Verheij, H., 2012. Cumulative impacts of road developments in floodplains. Transp. Res. Part D Transp. Environ. 17, 398-404. doi:10.1016/j.trd.2012.02.005

Bell, F.G., Stacey, T.R., Genske, D.D., 2000. Mining subsidence and its effect on the environment: some differing examples. Environ. Geol. 40, 135-152. doi:10.1007/s002540000140

Bentley, S.P., Siddle, H.J., 1996. Landslide research in the South Wales coalfield. Eng. Geol. 43, 65-80. doi:10.1016/0013-7952(95)00084-4

Bernard, L., Kanellopoulos, I., Annoni, A., Smits, P., 2005. The European geoportal--one step towards the establishment of a European Spatial Data Infrastructure. Comput. Environ. Urban Syst. 29, 15-31. 
Bielders, C.L., Ramelot, C., Persoons, E., 2003. Farmer perception of runoff and erosion and extent of flooding in the silt-loam belt of the Belgian Walloon Region. Environ. Sci. Policy 6, 8593. doi:10.1016/S1462-9011(02)00117-X

Biemelt, D., Schapp, A., Kleeberg, A., Grünewald, U., 2005. Overland flow, erosion, and related phosphorus and iron fluxes at plot scale: a case study from a non-vegetated lignite mining dump in Lusatia. Geoderma 129, 4-18. doi:10.1016/j.geoderma.2004.12.030

Blann, K.L., Anderson, J.L., Sands, G.R., Vondracek, B., 2009. Effects of Agricultural Drainage on Aquatic Ecosystems: A Review. Crit. Rev. Environ. Sci. Technol. 39, 909-1001. doi:10.1080/10643380801977966

Blanton, P., Marcus, W.A., 2009. Railroads, roads and lateral disconnection in the river landscapes of the continental United States. Geomorphology 112, 212-227. doi:10.1016/j.geomorph.2009.06.008

Blanton, P., Marcus, W.A., 2013. Transportation infrastructure, river confinement, and impacts on floodplain and channel habitat, Yakima and Chehalis rivers, Washington, USA Geomorphology 189, 55-65. doi:10.1016/j.geomorph.2013.01.016

Boardman, J., 2010. A short history of muddy floods. L. Degrad. Dev. 21, 303-309. doi:10.1002/ldr.1007

Boardman, J., 2013. Soil Erosion in Britain: Updating the Record. Agriculture 3, 418-442. doi:10.3390/agriculture3030418

Boardman, J., Evans, R., Ford, J., 2003. Muddy floods on the South Downs, southern England: problem and responses. Environ. Sci. Policy 6, 69-83. doi:10.1016/S1462-9011(02)00125-9

Boardman, J., Poesen, J., 2006. Soil Erosion in Europe: Major Processes, Causes and Consequences, in: John Wiley \& Sons, Ltd, (Ed.), Soil Erosion in Europe. pp. 477-487. doi:10.1002/0470859202.ch36

Boardman, J., Verstraeten, G., Bielders, C., 2006. Muddy Floods, in: Soil Erosion in Europe. John Wiley \& Sons, Ltd, pp. 743-755. doi:10.1002/0470859202.ch53

Boardman, J., Vandaele, K., 2010. Soil erosion, muddy floods and the need for institutional memory. Area 42, 502-513. doi:10.1111/j.1475-4762.2010.00948.x

Bochet, E., García-Fayos, P., Tormo, J., 2010. How can we control erosion of roadslopes in semiarid mediterranean areas? Soil improvement and native plant establishment. L. Degrad. Dev. 21, 110-121. doi:10.1002/ldr.911

Bochet, E., Neteler, M. (Eds.), 2012. Geospatial Free and Open Source Software in the 21st Century, Lecture Notes in Geoinformation and Cartography. Springer Berlin Heidelberg, Berlin, Heidelberg. doi:10.1007/978-3-642-10595-1

Borga, M., Tonelli, F., Selleroni, J., 2004. A physically based model of the effects of forest roads on slope stability. Water Resour. Res. 40. doi:10.1029/2004WR003238 
Borselli L., Cassi P., Torri D., 2008. Prolegomena to sediment and flow connectivity in the landscape: a GIS and field numerical assessment. Catena, 75(3), 268-277

Brown, A.G., Tooth, S., Chiverrell, R.C., Rose, J., Thomas, D.S.G., Wainwright, J., Bullard, J.E., Thorndycraft, V.R., Aalto, R., Downs, P., 2013. The Anthropocene: is there a geomorphological case? Earth Surf. Process. Landforms 38, 431-434. doi:10.1002/esp.3368

Brown, K.R., Michael Aust, W., McGuire, K.J., 2013. Sediment delivery from bare and graveled forest road stream crossing approaches in the Virginia Piedmont. For. Ecol. Manage. 310, 836-846. doi:10.1016/j.foreco.2013.09.031

Buchanan, B.P., Falbo, K., Schneider, R.L., Easton, Z.M., Walter, M.T., 2013. Hydrological impact of roadside ditches in an agricultural watershed in Central New York: implications for non-point source pollutant transport. Hydrol. Process. 27, 2422-2437. doi:10.1002/hyp.9305

Butzen, V., Seeger, M., Wirtz, S., Huemann, M., Mueller, C., Casper, M., Ries, J.B., 2014. Quantification of Hortonian overland flow generation and soil erosion in a Central European low mountain range using rainfall experiments. Catena 113, 202-212. doi:10.1016/j.catena.2013.07.008

Carluer, N., De Marsily, G., 2004. Assessment and modelling of the influence of man-made networks on the hydrology of a small watershed: implications for fast flow components, water quality and landscape management. J. Hydrol. 285, 76-95. doi:10.1016/j.jhydrol.2003.08.008

Cavalli, M., Trevisani, S., Comiti, F., Marchi, L., 2013. Geomorphometric assessment of spatial sediment connectivity in small Alpine catchments. Geomorphology 188, 31-41. doi:10.1016/j.geomorph.2012.05.007

Cerdà, A., Flanagan, D.C., le Bissonnais, Y., Boardman, J., 2009. Soil erosion and agriculture. Soil Tillage Res. 106, 107-108. doi:10.1016/j.still.2009.10.006

Cerdà, A., Brazier, R., Nearing, M., de Vente, J., 2013. Scales and erosion. Catena 102, 1-2. doi:10.1016/j.catena.2011.09.006

Changnon, S.A., Demissie, M., 1996. Detection of changes in streamflow and floods resulting from climate fluctuations and land use-drainage changes. Clim. Change 32, 411-421. doi:10.1007/BF00140354

Chen, A., Darbon, J., Morel, J.-M., 2014. Landscape evolution models: A review of their fundamental equations. Geomorphology 219, 68-86. doi:10.1016/j.geomorph.2014.04.037

Chen, J., Li, K., Chang, K.-J., Sofia, G., Tarolli, P., 2015. Open-pit mining geomorphic feature characterisation. Int. J. Appl. Earth Obs. Geoinf. 42, 76-86. doi:10.1016/j.jag.2015.05.001

Choi, Y., Park, H.-D., Sunwoo, C., 2008. Flood and gully erosion problems at the Pasir open pit coal mine, Indonesia: a case study of the hydrology using GIS. Bull. Eng. Geol. Environ. 67, 251-258. doi:10.1007/s10064-008-0131-8 
Collins, A.L., Walling, D.E., Stroud, R.W., Robson, M., Peet, L.M., 2010. Assessing damaged road verges as a suspended sediment source in the Hampshire Avon catchment, southern United Kingdom. Hydrol. Process. 24, 1106-1122. doi:10.1002/hyp.7573

Cortopassi, P.F., Daddi, M., D’Amato Avanzi, G., Giannecchini, R., Lattanzi, G., Merlini, A., Milano, P.F., 2008. Quarry waste and slope instability: preliminary assessment of some controlling factors in the Carrara marble basin (Italy). Ital. J Engi Geol Env. Spec. 99-118. doi:0.4408/IJEGE.2008-01.S-08

Costa, J.E., 1975. Effects of Agriculture on Erosion and Sedimentation in the Piedmont Province, Maryland. Geol. Soc. Am. Bull. 86, 1281-1286. doi:10.1130/00167606(1975)86<1281:EOAOEA>2.0.CO;2

Cots-Folch, R., Martínez-Casasnovas, A., Ramos, M.C., 2009. Agricultural trajectories in a Mediterranean mountain region (Priorat, NE Spain) as a consequence of vineyard conversion plans. Land Degradation \& Development 20: 1-13. DOI: 10.1002/ldr.856

Crist, E. 2013. On the Poverty of Our Nomenclature. Environ. Humanit. 3, 129-147.

Croke, J., Mockler, S., 2001. Gully initiation and road-to-stream linkage in a forested catchment, southeastern Australia. Earth Surf. Process. Landforms 26, 205-217. doi:10.1002/10969837(200102)26:2<205::AID-ESP168>3.0.CO;2-G

Croke, J., Mockler, S., Fogarty, P., Takken, I., 2005. Sediment concentration changes in runoff pathways from a forest road network and the resultant spatial pattern of catchment connectivity. Geomorphology 68, 257-268. doi:10.1016/j.geomorph.2004.11.020

D'Odorico, P., Rulli, M. C., 2013. The fourth food revolution. Nat. Geosci. 6, 417-418.

Debolini, M., Schoorl, J.M., Temme, A., Galli, M., Bonari, E., 2013. Changes in agricultural land use affecting future soil redistribution patterns: a case study in southern tuscany (Italy). L. Degrad. Dev. 26, 574-586. doi:10.1002/ldr.2217

Dewitte, O., Daoudi, M., Bosco, C., Van Den Eeckhaut, M., 2015. Predicting the susceptibility to gully initiation in data-poor regions. Geomorphology 228, 101-115. doi:10.1016/j.geomorph.2014.08.010

Diaz-Varela, R.A., Zarco-Tejada, P.J., Angileri, V., Loudjani, P., 2014. Automatic identification of agricultural terraces through object-oriented analysis of very high resolution DSMs and multispectral imagery obtained from an unmanned aerial vehicle. J. Environ. Manage. 134, 117-26. doi:10.1016/j.jenvman.2014.01.006

Dietrich, W.E., Perron, J.T., 2006. The search for a topographic signature of life. Nature 439, 411418. doi:10.1038/nature04452

Donnelly, L.J., 2009. A review of international cases of fault reactivation during mining subsidence and fluid abstraction. Q. J. Eng. Geol. Hydrogeol. 42 , 73-94. doi:10.1144/1470-9236/07-017 
Doolittle, W.E., 2006. Agricultural manipulation of floodplains in the southern Basin and Range Province. Catena 65, 179-199. doi:10.1016/j.catena.2005.11.002

Dotterweich, M., 2013. The history of human-induced soil erosion: Geomorphic legacies, early descriptions and research, and the development of soil conservation-A global synopsis, Geomorphology 201, 1-34, doi:10.1016/j.geomorph.2013.07.021.

Dotterweich, M., Stankoviansky, M., Minár, J., Koco, Š., Papčo, P., 2013. Human induced soil erosion and gully system development in the Late Holocene and future perspectives on landscape evolution: The Myjava Hill Land, Slovakia. Geomorphology 201, 227-245. doi:10.1016/j.geomorph.2013.06.023

Dotterweich, M., Ivester, A.H., Hanson, P.R., Larsen, D., Dye, D.H., 2015. Natural and human induced prehistoric and historical soil erosion and landscape development in southwestern Tennessee, USA. Anthropocene 8, 6-24. doi:10.1016/j.ancene.2015.05.003

Douglas, I., Lawson, N., 2000. The Human Dimensions of Geomorphological Work in Britain. J. Ind. Ecol. 4, 9-33. doi:10.1162/108819800569771

Douven, W., Buurman, J., Beevers, L., Verheij, H., Goichot, M., Nguyen, N.A., Truong, H.T., Ngoc, H.M., 2012. Resistance versus resilience approaches in road planning and design in delta areas: Mekong floodplains in Cambodia and Vietnam. J. Environ. Plan. Manag. 55, 1289-1310. doi:10.1080/09640568.2011.644848

Douven, W., Buurman, J., 2013. Planning practice in support of economically and environmentally sustainable roads in floodplains: the case of the Mekong delta floodplains. J. Environ. Manage. 128, 161-8. doi:10.1016/j.jenvman.2013.04.048

Dunne T., Leopold, L.B., 1987. Water in Environmental Planning, W. H. Freeman Co., San Francisco, 818 pp., 1978

Dunrud, C.R., 1984. Coal mine subsidence in western United States. Rev. Eng. Geol. 6, 151-194. doi:10.1130/REG6-p151

Earle, T., Doyle, D., 2008. The engineered landscapes of irrigation., in: Cliggett, L., Pool, C.A. (Eds.), Economies and Transformation of Landscape. Lanham, Md.: Altamira Press, pp. 19-46.

Eisenbies, M.H., Aust, W.M., Burger, J.A., Adams, M.B., 2007. Forest operations, extreme flooding events, and considerations for hydrologic modeling in the Appalachians-A review. For. Ecol. Manage. 242, 77-98. doi:10.1016/j.foreco.2007.01.051

Ellis, E.C., 2011. Anthropogenic transformation of the terrestrial biosphere. Philos. Trans. A. Math. Phys. Eng. Sci. 369, 1010-35. doi:10.1098/rsta.2010.0331

Erginal, A.E., Turkes, M., Ertek, T.A., Baba, A., Bayradkar, C., 2008. Geomorphological investigation of the excavation induced Dundar landslide, Bursa -Turkey. Geogr. Ann. Ser. A, Phys. Geogr. 90, 109-123. doi:10.1111/j.1468-0459.2008.00159.x 
Esling, S.P., Drake, L., 1988. Erosion of strip-mine spoil in lowa and its implications for erosion models. Geomorphology 1, 279-296. doi:10.1016/0169-555X(88)90001-3

Evrard, O., Bielders, C.L., Vandaele, K., van Wesemael, B., 2007. Spatial and temporal variation of muddy floods in central Belgium, off-site impacts and potential control measures. Catena 70, 443-454. doi:10.1016/j.catena.2006.11.011

Fabian, L., 2012. Extreme cities and isotropic territories: Scenarios and projects arising from the environmental emergency of the central Veneto città diffusa. Int. J. Disaster Risk Sci. 3, 11-22. doi:10.1007/s13753-012-0003-5

Ferrari, J.R., Lookingbill, T.R., McCormick, B., Townsend, P.A., Eshleman, K.N., 2009. Surface mining and reclamation effects on flood response of watersheds in the central Appalachian Plateau region. Water Resour. Res. 45, W04407. doi:10.1029/2008WR007109

Florsheim, J.L., Mount, J.F., Rutten, L.T., 2001. Effect of baselevel change on floodplain and fan sediment storage and ephemeral tributary channel morphology, Navarro River, California. Earth Surf. Process. Landforms 26, 219-232. doi:10.1002/1096-9837(200102)26:2<219::AIDESP169>3.0.CO;2-0

Florsheim, J.L., Pellerin, B.A., Oh, N.H., Ohara, N., Bachand, P.A.M., Bachand, S.M., Bergamaschi, B.A., Hernes, P.J., Kavvas, M.L., 2011. From deposition to erosion: Spatial and temporal variability of sediment sources, storage, and transport in a small agricultural watershed. Geomorphology 132, 272-286. doi:10.1016/j.geomorph.2011.04.037

Foley, J.A., Ramankutty, N., Brauman, K.A., Cassidy, E.S., Gerber, J.S., Johnston, M., Mueller, N.D., O'Connell, C., Ray, D.K., West, P.C., Balzer, C., Bennett, E.M., $\quad$ Carpenter, S.R., Hill, J., Monfreda, C., Polasky, S., $\quad$ Rockström,, J., Sheehan, J., Siebert, S., Tilman, D., Zaks, D.P.M., 2011. Solutions for a cultivated planet. Nature 478, 337-42.

Foley, J.A., Defries, R., Asner, G.P., Barford, C., Bonan, G., Carpenter, S.R., Chapin, F.S., Coe, M.T., Daily, G.C., Gibbs, H.K., Helkowski, J.H., Holloway, T., Howard, E.A., Kucharik, C.J., Monfreda, C., Patz, J.A., Prentice, I.C., Ramankutty, N., Snyder, P.K., 2005. Global consequences of land use. Science 309, 570-574. doi:10.1126/science.1111772

Francioni, M., Salvini, R., Stead, D., Giovannini, R., Riccucci, S., Vanneschi, C., Gullì, D., 2015. An integrated remote sensing-GIS approach for the analysis of an open pit in the Carrara marble district, Italy: Slope stability assessment through kinematic and numerical methods. Comput. Geotech. 67, 46-63. doi:10.1016/j.compgeo.2015.02.009

Fransen, P.J.B., Phillips, C.J., Fahey, B.D., 2001. Forest road erosion in New Zealand: overview. Earth Surf. Process. Landforms 26, 165-174. doi:10.1002/1096-9837(200102)26:2<165::AIDESP170>3.0.CO;2-\#

Fryirs, K.A., Brierley, G.J., 2012. Human Impacts on River Systems, in: Geomorphic Analysis of River Systems. John Wiley \& Sons, Ltd, pp. 269-296. doi:10.1002/9781118305454.ch13 
1035

1036

1037

1038

1039

1040

1041

1042

1043

1044

1045

1046

1047

1048

1049

1050

1051

1052

1053

1054

1055

1056

1057

1058

1059

1060

1061

1062

1063

1064

1065

1066

1067

1068

1069

1070

Fu, B., Newham, L.T.H., Ramos-Scharrón, C.E., 2010. A review of surface erosion and sediment delivery models for unsealed roads. Environ. Model. Softw. 25, 1-14. doi:10.1016/j.envsoft.2009.07.013

Fuller, I, Macklin, M.G., Richardson, J.M., 2015. The Geography of the Anthropocene in New Zealand: Differential River Catchment Response to Human Impact. Geogr. Res. n/a-n/a. doi:10.1111/1745-5871.12121

García-Ruiz, J.M., 2010. The effects of land uses on soil erosion in Spain: A review. Catena 81, 111. doi:10.1016/j.catena.2010.01.001

García-Ruiz, J.M., Beguería, S., Nadal-Romero, E., González-Hidalgo, J.C., Lana-Renault, N., Sanjuán, Y., 2015. A Meta-Analysis of soil erosion rates across the world. Geomorphology 239, 160-173. doi:10.1016/j.geomorph.2015.03.008

García-Ruiz, J.M., Lana-Renault, N., 2011. Hydrological and erosive consequences of farmland abandonment in Europe, with special reference to the Mediterranean region - A review. Agric. Ecosyst. Environ. 140, 317-338. doi:10.1016/j.agee.2011.01.003

García-Ruiz, J.M., Nadal-Romero, E., Lana-Renault, N., Beguería, S., 2013. Erosion in Mediterranean landscapes: Changes and future challenges. Geomorphology 198, 20-36. doi:10.1016/j.geomorph.2013.05.023

Goodchild, M.F., Guo, H., Annoni, A., Bian, L., de Bie, K., Campbell, F., Craglia, M., Ehlers, M., van Genderen, J., Jackson, D., Lewis, A.J., Pesaresi, M., Remetey-Fülöpp, G., Simpson, R., Skidmore, A., Wang, C., Woodgate, P., 2012. Next-generation Digital Earth. Proc. Natl. Acad. Sci. U.S.A. 109, 11088-94. doi:10.1073/pnas.1202383109

Gottschalk, L.C., 1945. Effects of Soil Erosion on Navigation in Upper Chesapeake Bay. Geogr. Rev. 35, 219-238. doi:10.2307/211476

Greenpeace, 2014. China, Inner Mongolia. Subsidence caused by lowering of water table from mining

[WWW

Document].

URL http://www.greenpeace.org/international/en/campaigns/climate-change/coal/Water-impacts/ (accessed 1.27.15).

Guerrero, F.M., Lozano, M., Rueda-Cantuche, J.M., 2008. Spain's greatest and most recent mine disaster. Disasters 32, 19-40. doi:10.1111/j.1467-7717.2007.01025.x

Guthrie, R., 2015. The catastrophic nature of humans. Nat. Geosci. 8, 421-422.

Hancock, G.R., Grabham, M.K., Martin, P., Evans, K.G., Bollhöfer, A., 2006. A methodology for the assessment of rehabilitation success of post mining landscapes--sediment and radionuclide transport at the former Nabarlek uranium mine, Northern Territory, Australia. Sci. Total Environ. 354, 103-19. doi:10.1016/j.scitotenv.2005.01.039

Hancock, G.R., Lowry, J.B.C., Moliere, D.R., Evans, K.G., 2008. An evaluation of an enhanced soil erosion and landscape evolution model: a case study assessment of the former Nabarlek 
uranium mine, Northern Territory, Australia. Earth Surf. Process. Landforms 33, 2045-2063. doi:10.1002/esp.1653

Hancock, G.R., Lowry, J.B.C., Coulthard, T.J., 2015. Catchment reconstruction - erosional stability at millennial time scales using landscape evolution models. Geomorphology 231, 1527. doi:10.1016/j.geomorph.2014.10.034

Harr, R.D., Harper, W.C., Krygier, J.T., Hsieh, F.S., 1975. Changes in storm hydrographs after road building and clear-cutting in the Oregon Coast Range. Water Resour. Res. 11, 436-444. doi:10.1029/WR011i003p00436

He, M., Tao, Z., Zhang, B., 2009. Application of remote monitoring technology in landslides in the Luoshan mining area. Min. Sci. Technol. 19, 609-614. doi:10.1016/S1674-5264(09)60113-7

Hearn, G.J., 1995. Landslide and erosion hazard mapping at Ok Tedi copper mine, Papua New Guinea. Q. J. Eng. Geol. Hydrogeol. 28, 47-60. doi:10.1144/GSL.QJEGH.1995.028.P1.05

Heitz, C., Spaeter, S., Auzet, A.-V., Glatron, S., 2009. Local stakeholders' perception of muddy flood risk and implications for management approaches: A case study in Alsace (France). Land use policy 26, 443-451. doi:10.1016/j.landusepol.2008.05.008

Herrera, G., Tomás, R., Vicente, F., Lopez-Sanchez, J.M., Mallorquí, J.J., Mulas, J., 2010. Mapping ground movements in open pit mining areas using differential SAR interferometry. Int. J. Rock Mech. Min. Sci. 47, 1114-1125. doi:10.1016/j.jirmms.2010.07.006

Herrera, G., Álvarez Fernández, M.I., Tomás, R., González-Nicieza, C., López-Sánchez, J.M., Álvarez Vigil, A.E., 2012. Forensic analysis of buildings affected by mining subsidence based on Differential Interferometry (Part III). Engineering Failure Analysis 24, 67-76, doi:10.1016/j.engfailanal.2012.03.003.Holmes, D.C., Pitty, A.E., Noy, D.J., 1993. Geomorphological and hydrogeological features of the Poços de Caldas caldera analogue study sites, in: Smellie, N.A.C.G.M.E.S.A.T. (Ed.), The Poços De Caldas Project: Natural Analogues of Processes in a Radioactive Waste Repository. Elsevier, Amsterdam, pp. 215247. doi: 10.1016/B978-0-444-89934-7.50010-4

Hölzel, H., Diekkrüger, B., 2012. Predicting the impact of linear landscape elements on surface runoff, soil erosion, and sedimentation in the Wahnbach catchment, Germany. Hydrol. Process. 26, 1642-1654. doi:10.1002/hyp.8282

Hooke, J.M., 2006. Human impacts on fluvial systems in the Mediterranean region. Geomorphology 79, 311-335.

Hooke, R.L., 1994. On the efficacy of humans as geomorphic agents. GSA Today 4, 217, 224225. doi:10.1130/0091-7613(2000)28<843:OTHOHA>2.0.

Hooke, R.L., 1999. Spatial distribution of human geomorphic activity in the United States: comparison with rivers. Earth Surf. Process. Landforms 24, 687-692. doi:10.1002/(SICI)10969837(199908)24:8<687::AID-ESP991>3.0.CO;2-\# 
Hooke, R.L., 2000. On the history of human as geomorphic agents. Geology 28, 843-846. doi:10.1130/0091-7613(2000)28<843:OTHOHA>2.0.CO

Jackson, D., 2014. Aznalcóllar abandons the green dream and votes to allow industry Read more http://www.davidjackson.info/blog/2014/01/05/aznalcollar-abandons-the-green-dream-andvotes-to-allow-industry [WWW Document]. URL Aznalcollar abandons the green dream and votes to allow industry (accessed 7.7.15).

Jambrik, R., 1995. Analysis of water level and land subsidence data from thorez open-pit mine, Hungary. Mine Water Environ. 14, 13-22. doi:10.1007/BF02914850

Jefferson, A.J., Wegmann, K.W., Chin, A., 2013. Geomorphology of the Anthropocene: Understanding the surficial legacy of past and present human activities. Anthropocene 2, 1-3. doi:10.1016/j.ancene.2013.10.005

Johnes, M., 2000. Aberfan and the Management of Trauma. Disasters 24, 1-17. doi:10.1111/14677717.00128

Jones, D.K., Baker, M.E., Miller, A.J., Jarnagin, S.T., Hogan, D.M., 2014. Tracking geomorphic signatures of watershed suburbanization with multitemporal LiDAR. Geomorphology 219, 4252. doi:10.1016/j.geomorph.2014.04.038

Jones, J.A., Swanson, F.J., Wemple, B.C., Snyder, K.U., 2000. Effects of roads on hydrology, geomorphology, and disturbance patches in stream networks. Conserv. Biol. 14, 76-85. doi:10.1046/j.1523-1739.2000.99083.x

Jordan, B.A., Annable, W.K., Watson, C.C., Sen, D., 2010. Contrasting stream stability characteristics in adjacent urban watersheds: Santa Clara Valley, California. River Res. Appl. 26, 1281-1297. doi:10.1002/rra.1333

Jordán-López, A., Martínez-Zavala, L., Bellinfante, N., 2009. Impact of different parts of unpaved forest roads on runoff and sediment yield in a Mediterranean area. Sci. Total Environ. 407, 937-44. doi:10.1016/j.scitotenv.2008.09.047

Jungerius, P.D., Matundura, J., van de Ancker, J.A.M., 2002. Road construction and gully erosion in West Pokot, Kenya. Earth Surf. Process. Landforms 27, 1237-1247. doi:10.1002/esp.423

Katpatal, Y.B., Patil, S.A., 2010. Spatial analysis on impacts of mining activities leading to flood disaster in the Erai watershed, India. J. Flood Risk Manag. 3, 80-87. doi:10.1111/j.1753318X.2009.01057.x

Katz, H.A., Daniels, J.M., Ryan, S., 2014. Slope-area thresholds of road-induced gully erosion and consequent hillslope-channel interactions. Earth Surf. Process. Landforms 39, 285-295. doi:10.1002/esp.3443

Kilmartin, M.P., 1989. Hydrology of reclaimed opencast coal-mined land: A review. Int. J. Surf. Mining, Reclam. Environ. 3, 71-82. doi:10.1080/09208118908944257 
Kircher, M., Roth, A., Adam, N., Kampes, B., Neugebauer, H.J., 2003. Remote sensing observation of mining induced subsidence by means of differential SAR-interferometry, in: Geoscience and Remote Sensing Symposium, 2003. IGARSS '03. Proceedings. 2003 IEEE International. pp. 209-211. doi:10.1109/IGARSS.2003.1293726

Kiss, T., Benyhe, B., 2015. Micro-topographical surface alteration caused by tillage and irrigation canal maintenance and its consequences on excess water development. Soil Tillage Res. 148, 106-118. doi:10.1016/j.still.2014.12.008

Klamath Resource Information System (KRIS), 2015. Roads and Upland Sediment Sources in Maine DPS Atlantic Salmon Watersheds [WWW Document]. URL http://www.krisweb.com/krissheepscot/krisdb/html/krisweb/watershed/roads_sediment.htm (accessed 7.7.15).

Knox, J.C., 2006. Floodplain sedimentation in the Upper Mississippi Valley: Natural versus human accelerated. Geomorphology 79, 286-310. doi:10.1016/j.geomorph.2006.06.031

Krause, S., Jacobs, J., Bronstert, A., 2007. Modelling the impacts of land-use and drainage density on the water balance of a lowland-floodplain landscape in northeast Germany. Ecol. Modell. 200, 475-492. doi:10.1016/j.ecolmodel.2006.08.015

Kumar, R., Jain, V., Prasad Babu, G., Sinha, R., 2014. Connectivity structure of the Kosi megafan and role of rail-road transport network. Geomorphology 227, 73-86. doi:10.1016/j.geomorph.2014.04.031

La Marche, J.L., Lettenmaier, D.P., 2001. Effects of forest roads on flood flows in the Deschutes River, Washington. Earth Surf. Process. Landforms 26, 115-134. doi:10.1002/10969837(200102)26:2<115::AID-ESP166>3.0.CO;2-O

Laimer, H.J., Mulleger, M., 2012. Geomorphological and geotechnical causes of anthropogenically induced rock-mass falls in the Wachau-Danube Valley (Bohemian Massif, Lower Austria). Geogr. Ann. Ser. A, Phys. Geogr. 94, 157-174. doi:10.1111/j.1468-0459.2012.00451.x

Latocha, A., 2014. Geomorphic connectivity within abandoned small catchments (Stołowe Mts, SW Poland). Geomorphology 212, 4-15. doi:10.1016/j.geomorph.2013.04.030.

Lenhart, C.F., Verry, E.S., Brooks, K.N., Magner, J.A., 2012. Adjustment of praire pothole streams to land-use, drainage and climate changes and consequences for turbidity impairment. River Res. Appl. 28, 1609-1619. doi:10.1002/rra.1549

Lewin, J., 2013. Enlightenment and the GM floodplain. Earth Surf. Process. Landforms 38, 17-29. doi:10.1002/esp.3230

Lewin, J., 2014. The English floodplain. Geogr. J. 180, 317-325. doi:10.1111/geoj.12093

Lewin, J., Macklin, M.G., 2010. Floodplain catastrophes in the UK Holocene: messages for managing climate change. Hydrol. Process. 24, 2900-2911. doi:10.1002/hyp.7704 
Lewin, J., Macklin, M.G. 2014, Marking time in Geomorphology: should we try to formalise an Anthropocene definition?. Earth Surf. Process. Landforms, 39: 133-137. doi: 10.1002/esp.3484

Li, X.B., Dong, L.J., Zhao, G.Y., Huang, M., Liu, A.H., Zeng, L.F., Dong, L., Chen, G.H., 2012. Stability analysis and comprehensive treatment methods of landslides under complex mining environment-A case study of Dahu landslide from Linbao Henan in China. Saf. Sci. 50, 695704. doi:10.1016/j.ssci.2011.08.049

Lieskovský, J., Kenderessy, P., 2014. Modelling the effect of vegetation cover and different tillage practices on soil erosion in vineyards: a case study in Vrable (Slovakia) using WATEM/SEDEM. L. Degrad. Dev. 25, 288-296. doi:10.1002/ldr.2162

Luce, C.H., 2002. Hydrological processes and pathways affected by forest roads: what do we still need to learn? Hydrol. Process. 16, 2901-2904. doi:10.1002/hyp.5061

Luce, C.H., Cundy, T.W., 1994. Parameter identification for a runoff model for forest roads. Water Resour. Res. 30, 1057-1069.

Luce, C.H., Wemple, B.C., 2001. Introduction to special issue on hydrologic and geomorphic effects of forest roads. Earth Surf. Process. Landforms 26, 111-113. doi:10.1002/10969837(200102)26:2<111::AID-ESP165>3.0.CO;2-2

Luttig, G.W., 1987. Approach to the problems of mineral resources extraction, environmental protection and land-use planning in the industrialised and developing countries. P. Arndt, G.W. Lütittig (Eds.), Miner. Resour. Extr. Environ. Prot. Land-use Plan. Ind. Dev. Countries, E. Schweizerbart, Stuttgart 7-13.

MacDonald, L.H., Sampson, R.W., Anderson, D.M., 2001. Runoff and road erosion at the plot and road segment scales, St John, US Virgin Islands. Earth Surf. Process. Landforms 26, 251-272. doi:10.1002/1096-9837(200103)26:3<251::AID-ESP173>3.0.CO;2-X

Macklin, M.G., Lewin, J., Jones, A.F., 2014. Anthropogenic alluvium: An evidence-based metaanalysis for the UK Holocene. Anthropocene 6, 26-38. doi:10.1016/j.ancene.2014.03.003

Madej, M.A., 2001. Erosion and sediment delivery following removal of forest roads. Earth Surf. Process. Landforms 26, 175-190. doi:10.1002/1096-9837(200102)26:2<175::AIDESP174>3.0.CO;2-N

Marion, D.A., Phillips, J.D., Yocum, C., Mehlhope, S.H., 2014. Stream channel responses and soil loss at off-highway vehicle stream crossings in the Ouachita National Forest. Geomorphology 216, 40-52. doi:10.1016/j.geomorph.2014.03.034

Martínez-Casasnovas, J.A., Sánchez-Bosch, I., 2000. Impact assessment of changes in land use/conservation practices on soil erosion in the Penedes-Anoia vineyard region (NE Spain). Soil Tillage Res. 57, 101-106. doi:10.1016/S0167-1987(00)00142-2

Martínez-Casasnovas, J.A., Ramos, M.C., Balasch, C., 2013. Precision analysis of the effect of ephemeral gully erosion on vine vigour using NDVI images, in: Stafford, J. (Ed.), Precision 
Agriculture '13 SE - 96. Wageningen Academic Publishers, pp. 777-783. doi:10.3920/978-908686-778-3_96

Martin-Vide, J., 2004. Spatial distribution of a daily precipitation concentration index in peninsular Spain. Int. J. Climatol. 24, 959-971. doi:10.1002/joc.1030

Massa, C., Bichet, V., Gauthier, É., Perren, B.B., Mathieu, O., Petit, C., Monna, F., Giraudeau, J., Losno, R., Richard, H., 2012. A 2500 year record of natural and anthropogenic soil erosion in South Greenland. Quat. Sci. Rev. 32, 119-130. doi:10.1016/j.quascirev.2011.11.014

Megahan, W.F., Wilson, M., Monsen, S.B., 2001. Sediment production from granitic cutslopes on forest roads in Idaho, USA. Earth Surf. Process. Landforms 26, 153-163. doi:10.1002/10969837(200102)26:2<153::AID-ESP172>3.0.CO;2-0

Meng, L., Feng, Q., Wu, K., Meng, Q., 2012. Quantitative evaluation of soil erosion of land subsided by coal mining using RUSLE. Int. J. Min. Sci. Technol. 22, 7-11. doi:10.1016/j.ijmst.2011.06.001

Merten, G.H., Minella, J.P.G., 2013. The expansion of Brazilian agriculture: Soil erosion scenarios. Int. Soil Water Conserv. Res. 1, 37-48. doi:10.1016/S2095-6339(15)30029-0

Micheletti, N., Chandler, J.H., Lane, S.N., 2015. Investigating the geomorphological potential of freely available and accessible structure-from-motion photogrammetry using a smartphone. Earth Surf. Process. Landforms 40, 473-486. doi:10.1002/esp.3648

Minnesota Department of Natural Resources, 2015. LiDARElevation Data for Minnesota [WWW Document]. URL http://arcgis.dnr.state.mn.us/maps/mntopo/ (accessed 7.7.15).

Monastersky, R., 2015. Anthropocene: The human age. Nature 519, 144-147. doi:10.1038/519144a

Montgomery, D.R., 1994. Road surface drainage, channel initiation, and slope instability. Water Resour. Res. 30, 1925-1932. doi:10.1029/94WR00538

Montgomery, D.R., 2007a. Is agriculture eroding civilization's foundation? GSA Today 17, 1-9. doi:10.1130/GSAT01710A.1

Montgomery, D.R. 2007b. Soil erosion and agricultural sustainability. Proceedings of the National Academy of Sciences 104 : 13268-13272. DOI: 10.1073/pnas.0611508104 [online] Available from: http://www.pnas.org/content/104/33/13268.abstract

Mossa, J., James, L.A., 2013. 13.6 Impacts of Mining on Geomorphic Systems, in: Treatise on Geomorphology. Elsevier, pp. 74-95. doi:10.1016/B978-0-12-374739-6.00344-4

Muñoz-Robles, C., Reid, N., Frazier, P., Tighe, M., Briggs, S. V., Wilson, B., 2010. Factors related to gully erosion in woody encroachment in south-eastern Australia. Catena 83, 148-157. doi:10.1016/j.catena.2010.08.002

Nebraska State Patrol, 2002. The Flood [WWW Document]. URL http://www.transportation.nebraska.gov/closure/ (accessed 7.7.15). 
Negley, T.L., Eshleman, K.N., 2006. Comparison of stormflow responses of surface-mined and forested watersheds in the Appalachian Mountains, USA. Hydrol. Process. 20, 3467-3483. doi:10.1002/hyp.6148

Nicolau, J.-M., 2002. Runoff generation and routing on artificial slopes in a Mediterraneancontinental environment: the Teruel coalfield, Spain. Hydrol. Process. 16, 631-647. doi:10.1002/hyp.308

Nyssen, J., Poesen, J., Moeyersons, J., Luyten, E., Veyret-Picot, M., Deckers, J., Haile, M., Govers, G., 2002. Impact of road building on gully erosion risk: a case study from the Northern Ethiopian Highlands. Earth Surf. Process. Landforms 27, 1267-1283. doi:10.1002/esp.404

O'Connell, P.E., Ewen, J., O'Donnell, G., Quinn, P., 2007. Is there a link between agricultural landuse management and flooding? Hydrol. Earth Syst. Sci. 11, 96-107.

Palmer, R.C., Smith, R.P., 2013. Soil structural degradation in SW England and its impact on surface-water runoff generation. Soil Use Manag. 29, 567-575. doi:10.1111/sum.12068

Panilas, S., Petalas, C.P., Gemitzi, A., 2008. The possible hydrologic effects of the proposed lignite open-cast mining in Drama lignite field, Greece. Hydrol. Process. 22, 1604-1617. doi:10.1002/hyp.6729

Pankow, K.L., Moore, J.R., Hale, J.M., Koper, K.D., Kubacki, T., Whidden, K.M., McCarter, M.K., 2013. GSA Today - Massive landslide at Utah copper mine generates wealth of geophysical data. GSA Today 4-9. doi:10.1130/GSATG191A

Passalacqua, P., Belmont, P., Staley, D.M., Simley, J.D., Arrowsmith, J.R., Bode, C.A., Crosby, C., DeLong, S.B., Glenn, N.F., Kelly, S.A., Lague, D., Sangireddy, H., Schaffrath, K., Tarboton, D.G., Wasklewicz, T., Wheaton, J.M., 2015. Analyzing high resolution topography for advancing the understanding of mass and energy transfer through landscapes: A review. Earth-Science Rev. 148, 174-193. doi:10.1016/j.earscirev.2015.05.012

Pechenick, A.M., Rizzo, D.M., Morrissey, L.A., Garvey, K.M., Underwood, K.L., Wemple, B.C., 2014. A multi-scale statistical approach to assess the effects of connectivity of road and stream networks on geomorphic channel condition. Earth Surf. Process. Landforms 39, 1538-1549. doi:10.1002/esp.3611

Peila, D., Patrucco, M., Falancesca, M., 2011. Quantification and Management of Rockfall Risk in Opencast Quarrying Activities. Environ. Eng. Geosci. 17, 39-51. doi:10.2113/gseegeosci.17.1.39

Penna, D., Borga, M., Aronica, G.T., Brigandì, G., Tarolli, P., 2014. Predictive power of a shallow landslide model in a high-resolution landscape: dissecting the effects of forest roads. Hydrology and Earth System Sciences 18, 2127-2139. doi:10.5194/hess-18-2127-2014.

Perkmann, M., Schildt, H., 2014. Open data partnerships between firms and universities: The role of boundary organizations. Res. Policy 44, 1133-1143. 
Petley, D., Hearn, G., Hart, A., Rosser, N., Dunning, S., Oven, K., Mitchell, W., 2007. Trends in landslide occurrence in Nepal. Nat. Hazards 43, 23-44. doi:10.1007/s11069-006-9100-3

Prosdocimi, M., Calligaro, S., Sofia, G., Dalla Fontana, G., Tarolli, P., 2015. Bank erosion in agricultural drainage networks: new challenges from Structure-from-Motion photogrammetry for post-event analysis. Earth Surf. Process. Landforms 40, 1891-1906. doi:10.1002/esp.3767

Ramani, R. V, 1995. Mining disasters caused and controlled by mankind: the case for coal mining and other minerals. Nat. Resour. Forum 19, 233-242. doi:10.1111/j.1477-8947.1995.tb00613.x

Reid, L.M., Dunne, T., 1984. Sediment Production From Forest Road Surfaces. Water Resour. Res. 20, 1753-1761. doi:10.1029/WR020i011p01753

Renwick, A., Jansson, T., Verburg, P.H., Revoredo-Giha, C., Britz, W., Gocht, A., McCracken, D., 2013. Policy reform and agricultural land abandonment in the EU. Land use policy 30, 446457. doi:10.1016/j.landusepol.2012.04.005

Richards, T., 1966. The Aberfan Disaster [WWW Document]. URL http://www.alangeorge.co.uk/AberfanDisaster_Page2.htm (accessed 7.7.15).

Rico, M., Benito, G., Díez-Herrero, A., 2008a. Floods from tailings dam failures. J. Hazard. Mater. 154, 79-87. doi:10.1016/j.jhazmat.2007.09.110

Rico, M., Benito, G., Salgueiro, A.R., Díez-Herrero, A., Pereira, H.G., 2008b. Reported tailings dam failures. A review of the European incidents in the worldwide context. J. Hazard. Mater. 152, 846-52. doi:10.1016/j.jhazmat.2007.07.050

Rivas, V., Cendrero, A., Hurtado, M., Cabral, M., Giménez, J., Forte, L., del Río, L., Cantú, M., Becker, A., 2006. Geomorphic consequences of urban development and mining activities; an analysis of study areas in Spain and Argentina. Geomorphology 73, 185-206. doi:10.1016/j.geomorph.2005.08.006

Rogich, D.G., and Matos, G.R., 2008, The global flows of metals and minerals: U.S. Geological Survey Open-File Report 2008-1355, 11 p., available only online at http://pubs.usgs.gov/of/2008/1355/.

Sanchez, C.E., Karl Wood, M., 1989. Infiltration rates and erosion associated with reclaimed coal mine spoils in west central New Mexico. Landsc. Urban Plan. 17, 151-168. doi:10.1016/01692046(89)90023-6

Schilling, K.E., Helmers, M., 2008. Effects of subsurface drainage tiles on streamflow in lowa agricultural watersheds: Exploratory hydrograph analysis. Hydrol. Process. 22, 4497-4506. doi:10.1002/hyp.7052

Schilling, K.E., Jha, M.K., Zhang, Y.-K., Gassman, P.W., Wolter, C.F., 2008. Impact of land use and land cover change on the water balance of a large agricultural watershed: Historical effects and future directions. Water Resour. Res. 44. doi:10.1029/2007WR006644 
Schottler, S.P., Ulrich, J., Belmont, P., Moore, R., Lauer, J.W., Engstrom, D.R., Almendinger, J.E., 2014. Twentieth century agricultural drainage creates more erosive rivers. Hydrol. Process. 28 , 1951-1961. doi:10.1002/hyp.9738

Scott, M.J., Statham, I., 1998. Development advice maps: mining subsidence. Geol. Soc. London, Eng. Geol. Spec. Publ. 15 , 391-400. doi:10.1144/GSL.ENG.1998.015.01.39

Sherba, J., Blesius, L., Davis, J., 2014. Object-Based Classification of Abandoned Logging Roads under Heavy Canopy Using LiDAR. Remote Sens. 6, 4043-4060. doi:10.3390/rs6054043

Sidle, R.C., Ziegler, A.D., 2012. The dilemma of mountain roads. Nat. Geosci 5, 437-438.

Smil, V., 2015. It's too soon to call this the Anthropocene era. IEEE Spectrum (posted 27 May 2015).

Sofia, G., Fontana, G.D., Tarolli, P., 2014a. High-resolution topography and anthropogenic feature extraction: Testing geomorphometric parameters in floodplains. Hydrol. Process. 28, 20462061. doi:10.1002/hyp.9727

Sofia, G., Marinello, F., Tarolli, P., 2014b. A new landscape metric for the identification of terraced sites: The Slope Local Length of Auto-Correlation (SLLAC). ISPRS J. Photogramm. Remote Sens. 96, 123-133. doi:10.1016/j.isprsjprs.2014.06.018

Sofia, G., Prosdocimi, M., Dalla Fontana, G., Tarolli, P., 2014c. Modification of artificial drainage networks during the past half-century: Evidence and effects in a reclamation area in the Veneto floodplain (Italy). Anthropocene 6, 48-62. doi:10.1016/j.ancene.2014.06.005

Sofia, G., Marinello, F., Tarolli, P., 2015. Quantitative geomorphologic portrait of anthropogenic landscapes: road networks. Earth Surface Processes and Landforms, doi: 10.1002/esp.3842.Steffen, W., Crutzen, J., McNeill, J.R., 2007. The Anthropocene: are humans now overwhelming the great forces of Nature? Ambio 36, 614-621. doi:10.1579/00447447(2007)36[614:TAAHNO]2.0.CO;2

Stöcker, C., Eltner, A., Karrasch, P., 2015. Measuring gullies by synergetic application of UAV and close range photogrammetry - A case study from Andalusia, Spain. Catena 132, 1-11. doi:10.1016/j.catena.2015.04.004

Stockmann, U., Minasny U., McBratney, A.B., 2014. How fast does soil grow? Geoderma 216, 4861. doi:10.1016/j.geoderma.2013.10.007.

Sugden, B.D., Woods, S.W., 2007. Sediment Production From Forest Roads in Western Montana1. JAWRA J. Am. Water Resour. Assoc. 43, 193-206. doi:10.1111/j.17521688.2007.00016.x

Superson, J., Rodzik, J., Reder, J., 2014. Natural and human influence on loess gully catchment evolution: A case study from Lublin Upland, E Poland. Geomorphology 212, 28-40. doi:10.1016/j.geomorph.2013.09.011 
1355

1356

1357

1358

1359

1360

1361

1362

1363

1364

1365

1366

1367

1368

1369

1370

1371

1372

1373

1374

1375

1376

1377

1378

1379

1380

1381

1382

1383

1384

1385

1386

1387

1388

1389

1390

Swanson, F.J., Dyrness, C.T., 1975. Impact of clear-cutting and road construction on soil erosion by landslides in the western Cascade Range, Oregon. Geol. 3 , 393-396. doi:10.1130/00917613(1975)3<393:IOCARC>2.0.CO;2

Tague, C., Band, L., 2001. Simulating the impact of road construction and forest harvesting on hydrologic response. Earth Surf. Process. Landforms 26, 135-151. doi:10.1002/10969837(200102)26:2<135::AID-ESP167>3.0.CO;2-J

Takken, I., Croke, J., Lane, P., 2008. Thresholds for channel initiation at road drain outlets. Catena 75, 257-267. doi:10.1016/j.catena.2008.07.001

Tarolli, P., 2014. High-resolution topography for understanding Earth surface processes: Opportunities and challenges. Geomorphology 216, 295-312. doi:10.1016/j.geomorph.2014.03.008

Tarolli, P., Calligaro, S., Cazorzi, F., Dalla Fontana, G., 2013. Recognition of surface flow processes influenced by roads and trails in mountain areas using high-resolution topography. Eur. J. Remote Sens. 46, 176 - 197. doi:10.5721/EuJRS20134610

Tarolli, P., Preti, F., Romano, N., 2014. Terraced landscapes: From an old best practice to a potential hazard for soil degradation due to land abandonment. Anthropocene 6, 10-25. doi:10.1016/j.ancene.2014.03.002

Tarolli, P., Sofia, G., Calligaro, S., Prosdocimi, M., Preti, F., Dalla Fontana, G., 2015. Vineyards in terraced landscapes: new opportunities from LiDAR data. L. Degrad. Dev. 26, 92-102. doi:10.1002/ldr.2311

Tetzlaff, B., Friedrich, K., Vorderbrügge, T., Vereecken, H., Wendland, F., 2013. Distributed modelling of mean annual soil erosion and sediment delivery rates to surface waters. Catena 102, 13-20. doi:10.1016/j.catena.2011.08.001

Thurman, N.C., Sencindiver, J.C., 1986. Properties, classification, and interpretations of minesoils at two sites in West Virginia. Soil Sci. Soc. Am. J. 50:181-185

Thomaz, E.L., Vestena, L.R., Ramos Scharrón, C.E., 2014. The effects of unpaved roads on suspended sediment concentration at varying spatial scales - a case study from Southern Brazil. Water Environ. J. 28, 547-555. doi:10.1111/wej.12070

Trabucchi, M., Puente, C., Comin, F., Olague, G., Smith, S., 2012. Mapping erosion risk at the basin scale in a Mediterranean environment with opencast coal mines to target restoration actions. Reg. Environ. Chang. 12, 675-687. doi:10.1007/s10113-012-0278-5

Trizzino, R., 2015. Numerical Modeling of Interrelationships Between Linear Transportation Infrastructures and Hydro-geological Hazard in Floodplains, in: Lollino, G., Giordan, D., Thuro, K., Carranza-Torres, C., Wu, F., Marinos, P., Delgado, C. (Eds.), Engineering Geology for Society and Territory - Volume 6 SE - 54. Springer International Publishing, pp. 317-321. doi:10.1007/978-3-319-09060-3_54 
Van Meerveld, H.J., Baird, E.J., Floyd, W.C., 2014. Controls on sediment production from an unpaved resource road in a Pacific maritime watershed. Water Resour. Res. 50, 4803-4820. doi:10.1002/2013WR014605

Van Oost, K., Govers, G., De Alba, S., Quine, T.A., 2006. Tillage erosion: a review of controlling factors and implications for soil quality. Prog. Phys. Geogr. 30, 443-466. doi:10.1191/0309133306pp487ra

Verburg, P., van Berkel, D., van Doorn, A., van Eupen, M., van den Heiligenberg, H.R.M., 2010. Trajectories of land use change in Europe: a model-based exploration of rural futures. Landsc. Ecol. 25, 217-232. doi:10.1007/s10980-009-9347-7

Vidal, O., Goffe, B., Arndt, N., 2013. Metals for a low-carbon society. Nat. Geosci 6, 894-896.

Vis, M., Klijn, F., De Bruijn, K.M., Van Buuren, M., 2003. Resilience strategies for flood risk management in the Netherlands. Int. J. River Basin Manag. 1, 33-40. doi:10.1080/15715124.2003.9635190

Visconti, G. 2014. Anthropocene: another academic invention? Rend. Fis. Acc. Lincei 25 (3): $381-$ 392. doi:10.1007/s12210-014-0317-x.

Wasklewicz, T., Scheinert, C., 2016. Development and maintenance of a telescoping debris flow fan in response to human-induced fan surface channelization, Chalk Creek Valley Natural Debris Flow Laboratory, Colorado, USA. Geomorphology 252, 51-65. doi:10.1016/j.geomorph.2015.06.033

Wei, Z., Yin, G., Wan, L., Shen, L., 2008. Case history of controlling a landslide at Panluo open-pit mine in China. Environ. Geol. 54, 699-709. doi:10.1007/s00254-007-0839-y

Wemple, B.C., Jones, J.A., Grant, G.E., 1996. Channel network extension by logging roads in two basins, western Cascades, Oregon. JAWRA Journal of the American Water Resources Association 32, 1195-1207. doi:10.1111/j.1752-1688.1996.tb03490.x

Wemple, B.C., Swanson, F.J., Jones, J.A., 2001. Forest roads and geomorphic process interactions, Cascade Range, Oregon. Earth Surf. Process. Landforms 26, 191-204. doi:10.1002/1096-9837(200102)26:2<191::AID-ESP175>3.0.CO;2-U

Wemple, B.C., Jones, J.A., 2003. Runoff production on forest roads in a steep, mountain catchment. Water Resour. Res. 39(8), 1220.

Westoby, M.J., Brasington, J., Glasser, N.F., Hambrey, M.J., Reynolds, J.M., 2012. "Structurefrom-Motion" photogrammetry: A low-cost, effective tool for geoscience applications. Geomorphology 179, 300-314. doi:10.1016/j.geomorph.2012.08.021

Wheater, H., Evans, E., 2009. Land use, water management and future flood risk. Land use policy 26, S251-S264. doi:10.1016/j.landusepol.2009.08.019 
Whittaker, B.N., Reddish, D.J., 1989. Subsidence. Occurrence, Prediction and Control . Elsevier [online] Available from: http://www.elsevier.com/books/subsidence/whittaker/978-0-444-872746\# (Accessed 15 October 2015)

Wilkinson, B.H., 2005. Humans as geologic agents: A deep-time perspective. Geology 33, 161. doi:10.1130/G21108.1

Wohl, E., 2013. Wilderness is dead: Whither critical zone studies and geomorphology in the Anthropocene? Anthropocene 2, 4-15. doi:10.1016/j.ancene.2013.03.001

Woldai, T., Oppliger, G., Taranik, J., 2009. Monitoring dewatering induced subsidence and fault reactivation using interferometric synthetic aperture radar. Int. J. Remote Sens. 30, 1503-1519. doi:10.1080/01431160802509033

Wolf, D., Seim, A., Faust, D., 2014. Fluvial system response to external forcing and human impact - Late Pleistocene and Holocene fluvial dynamics of the lower Guadalete River in western Andalucía (Spain). Boreas 43, 422-449. doi:10.1111/bor.12044

Wolkersdorfer, C., Thiem, G., 1999. Ground water withdrawal and land subsidence in northeastern Saxony (Germany). Mine Water Environ. 18, 81-92. doi:10.1007/BF02687252

Wulder, M. A., Coops, N. C., 2014. Satellites: Make Earth observations open access. Nature 513, $30-1$.

Zajac, T., Korzeniak, J., Solarz, W., Zajac, K., Krol, W., Krzysciak-Kosinska, R., 2002. Geomorphic structure and land cover of extensively managed floodplains of the Nida River. Nat. Conserv. 59, 91-97.

Zalasiewicz, J., Smith, A., Hounslow, M., Williams, M., Gale, A., Powell, J., Waters, C., Barry, T., Bown, P., Brenchley, P., Cantrill, D., Gibbard, P., Gregory, F., Knox, R., Marshall, J., Oates, M., Rawson, P., Stone, P., Trewin, N., 2008. Are we now living in the Anthropocene. GSA Today 18, 4-8. doi:10.1130/GSAT01802A.1

Zalasiewicz, J., Waters, C.N., Williams, M., 2014. Human bioturbation, and the subterranean landscape of the Anthropocene. Anthropocene 6, 3-9. doi:10.1016/j.ancene.2014.07.002

Zalasiewicz, J., Williams, M., Fortey, R., Smith, A., Barry, T.L., Coe, A.L., Bown, P.R., Rawson, P.F., Gale, A., Gibbard, P., Gregory, F.J., Hounslow, M.W., Kerr, A.C., Pearson, P., Knox, R., Powell, J., Waters, C., Marshall, J., Oates, M., Stone, P., 2011a. Stratigraphy of the Anthropocene. Philos. Trans. R. Soc. London A Math. Phys. Eng. Sci. 369, 1036-1055. doi:10.1098/rsta.2010.0315

Zalasiewicz, J., Williams, M., Haywood, A., Ellis, M., 2011b. The Anthropocene: a new epoch of geological time? Philos. Trans. A. Math. Phys. Eng. Sci. 369, 835-41. doi:10.1098/rsta.2010.0339 
1459 Ziegler, A.D., Giambelluca, T.W., 1997. Importance of rural roads as source areas for runoff in 1460 mountainous areas of northern Thailand. J. Hydrol. 196, 204-229. doi:10.1016/S00221461 1694(96)03288-X

1462 Ziegler, A.D., Giambelluca, T.W., Sutherland, R.A., Nullet, M.A., Yarnasarn, S., Pinthong, J., 1463 Preechapanya, P., Jaiaree, S., 2004. Toward understanding the cumulative impacts of roads in 1464 upland agricultural watersheds of northern Thailand. Agric. Ecosyst. Environ. 104, 145-158. 1465 doi:10.1016/j.agee.2004.01.012 


\section{Table captions}

1467 Tab. 1. Literature on surface mining and the connected geomorphic processes.

1468 Tab. 2. Literature on roads and geomorphic processes.

1469 Tab. 3. Collection of review papers and journal special issues that underline the deep 1470 connection between agriculture and surface processes.

1471 Tab. 4. Collection of the most recent works dealing with HRT and anthropogenic 1472 environments. 


\section{Figure captions}

Fig. 1. (a) Hypothetical frequency distributions (pdfs) of landform properties for the present Earth and an abiotic Earth (from Dietrich and Perron, 2006); (b) pdfs of slope for natural and terraced landscapes in northern (Trento province) and southern Italy (Salerno province), respectively. Fig. $1 \mathrm{~b}$ also shows shaded relief maps of the two study areas obtained from $2 \mathrm{~m}$ LiDAR DTM.

Fig. 2. Worldwide surface mining from Google Earth imagery: (a) Minnesota (USA), (b) Germany, (c) Utah (USA), (d) Australia, (e) Chile, (f) Egypt, (g) India, (h) Indonesia, (i) Spain, (I) Italy, (m) China, (n) Norway, (o) Russia and (p) South-Africa.

Fig. 3. Surface mining in the Rheinald-Pfalz region (Germany) (photo by G. Sofia) (a) and erosion of tailing piles in a copper mine (Agency, 1972).

Fig. 4. Soil erosion rates for mining landscapes reported in various units in the literature and converted to equivalent lowering rates (assuming a soil bulk density of $2000 \mathrm{~kg} \mathrm{~m}^{-3}$ for construction/mining together, and $1500 \mathrm{~kg} \mathrm{~m}^{-3}$ for soil erosion at the hillslope scale) compared to gently sloping lowland landscapes (cratons), moderate gradient hillslopes of soil-mantled terrain (soil-mantled) and steep, tectonically active alpine topography (Alpine) erosion rate ranges published in Montgomer (2007b).

Fig. 5. Baorixile, Hulunbeir, Inner Mongolia: grassland subsidence due to the lowering of the water table caused by coal mining (Greenpeace, 2014). @ Lu Guang/Greenpeace

Fig. 6. The Aberfan (UK) Disaster (21 October 1966): a wave of coal deposits from surface mining slid down the Aberfan Valley. (Richards, 1966)

Fig. 7. Aznalcóllar (Seville, Spain). The tail of a mine broke in 1998 and polluted beyond recovery almost 5,000 ha of natural land on both sides of a $63 \mathrm{~km}$ stretch of river, including a vast swath of Doñana Natural Park (Jackson, 2014)

Fig. 8. Nepal. (a) Forested landscapes without roads, as seen in 2008 from Google Earth, and (b) landslides along the newly constructed rural road, as shown in the 2010 Google Earth image. 
1498 Fig. 9. Road effects on runoff. (a) An agricultural road intercepting snowmelt in the Rheinald-Pfalz 1499 region (Germany) (photo by G.Sofia) (a), and an agricultural road intercepting and concentrating 1500 runoff in Tuscany (Italy) (photo by S.Calligaro).

1501 Fig. 10. Road effects on streams and erosion. (a) Off-highway trail capturing a local stream. (b) 1502 sand building up at a road crossing and washing down into the West Branch of the Sheepscot 1503 River, as indicated by the gully between the third and fourth guard rails (Klamath Resource 1504 Information System -KRIS-, 2015).

1505 Fig. 11. Nebraska (USA): receding floodwaters rush through a culvert and tear out the surrounding 1506 earth (a) and an aerial view of the damaged approaches showing the receding flood waters (b). 1507 (Nebraska State Patrol, 2002).

1508 Fig. 12. Changes in agricultural practices in Italy: (a) terraces in 2006 that were (b) progressively 1509 recolonized by forest in 2014 (Monterosso al Mare, La Spezia, Italy); (c) agriculture in 1945 that 1510 was (d) lost to urbanization in 2015 (Florence, Italy). Changes in crops practices in Kansas (USA) 1511 (e) in 1991 and (f) after the implementation of centre-pivot irrigation in 2014. (Images from Google 1512 Earth).

1513 Fig. 13. Failure of the reclamation network in Veneto (Italy) (a) area as seen on Google Street View 1514 ( in normal condition and (b) after a few hours of rain in Nov. 2014 (photo by G. Sofia)

1515 Fig. 14. Soil erosion rates for agriculture reported in Garcia-Ruiz et al. (2015) converted to 1516 equivalent lowering rates, assuming a soil bulk density of $1200 \mathrm{~kg} \mathrm{~m}^{-3}$, compared to gently sloping 1517 lowland landscapes (cratons), moderate gradient hillslopes of soil-mantled terrain (soil-mantled) 1518 and steep tectonically active alpine topography (Alpine) erosion rate ranges published in 1519 Montgomery (2007b).

1520 Fig. 15. Bingham Canyon Mine (A) (UT, USA) and Hull-Rust-Mahoning Mine (B) (MN, USA) as 1521 seen from Google Earth (a and d, respectively) and depicted by a 2 m LiDAR DTM (b and d). (c) 1522 and (f) present the SLLAC maps as derived according to the method of Sofia et al., (2014b). The 1523 water bodies are coloured in blue in (f); they are completely flat areas where the cross-correlation 1524 is zero. 
1525 Fig. 16. Mining area in Spain in 2005 (a) and 2008 (e); image gradients for the two years (b and f 1526 for 2005 and 2008, respectively) and the derived GLLAC (c) and (g), computed using the same 1527 parameters presented in Sofia et al., (2014b). Figures (d) and (h) show the area automatically 1528 identified as anthropogenic, starting from the GLLAC images.

1529 Fig. 17. Connectivity Index (Cavalli et al., 2013) for the Lookout Creek watershed (OR, USA). The 1530 connectivity is evaluated in terms of $(a, b$ and $h)$ sediment delivery across the entire drainage 1531 system (as in the potential connection of sediment between the hillslopes and catchment outlet) 1532 and the sediment coupling-decouplings between the hillslopes and main channels (c, $f$ and $i)$ and 1533 the hillslopes and the road network ( $d, g$ and $\mathrm{I})$.

1534 Fig. 18. RPII (Tarolli et al., 2013) evaluated for (a) the areas shown in (Fig. 17e, 17f and 17g) and 1535 (b) the areas shown in (Fig. 17h, 17i and 17l). The arrows in (a) highlight slides that were probably 1536 induced by the presence of the road, and the road caused the flow alteration. The arrows in (b) 1537 highlight the connection of flows induced by the road. 
Tab. 1

Surface mining, land displacement and erosion

Surface mining and land subsidence
Luttig (1987)

Hooke (1999)

Esling and Drake (1988)

Sanchez and Karl Wood (1989)

Douglas and Lawson (2000)

Nicolau (2002)

Biemelt et al. (2005)

Rivas et al. (2006)

Hancock et al. (2006)

Choi et al. (2008)

Trabucchi et al. (2012)

Meng et al. (2012)

Dunrud (1984)

Whittaker and Reddish (1989)

Jambrik (1995)

Scott and Statham (1998)

Wolkersdorfer and Thiem (1999)

Bell et al. (2000)

Kircher et al. (2003)

Panilas et al. (2008)

Donnelly (2009)

Woldai et al. (2009)

Herrera et al., (2010)

Hearn (1995)

Ramani (1995)

Bentley and Siddle (1996)

Johnes (2000)

Baroni et al. (2000)

Wei et al. (2008)

Erginal et al. (2008)

Cortopassi et al. (2008)

Guerrero et al. (2008)

Rico et al. (2008a) and Rico et al. (2008b)

He et al., (2009)

Peila et al. (2011)

Li et al. (2012)

Laimer and Mulleger (2012)

Kilmartin (1989)

Holmes et al. (1993)

Negley and Eshleman (2006)

Ferrari et al. (2009)

Katpatal and Patil (2010) 
Tab. 2

Luce and Wemple (2001)

Croke and Mockler (2001);

Fransen et al. (2001);

Roads in mountainous / hilly landscapes

La Marche and Lettenmaier (2001);

Madej (2001);

Megahan et al. (2001);

Tague and Band (2001)

Harr et al. (1975)

Jones et al. (2000)

Fransen et al. (2001)

Wemple et al. (2001)

MacDonald et al. (2001)

MacDonald et al. (2001)

Luce (2002)

Wemple and Jones (2003)

Ziegler et al. (2004)

Borga et al. (2004)

Eisenbies et al. (2007)

Sugden and Woods (2007)

Roads, runoff and erosion/sediment Jordán-López et al. (2009)

Bochet et al. (2010)

Fu et al. (2010)

Collins et al. (2010)

Hölzel and Diekkrüger (2012)

Tarolli et al. (2013)

Penna et al. (2014)

Thomaz et al. (2014)

Butzen et al. (2014)

Marion et al. (2014)

Brown et al. (2013)

van Meerveld et al. (2014)

Wemple et al. (1996)

Nyssen et al. (2002)

Jungerius et al., (2002)

Takken et al. (2008)

Gully erosion

Muñoz-Robles et al. (2010)

Katz et al. (2014)

Superson et al. (2014)

Dewitte et al., (2015)

Croke et al. (2005)

Connectivity

Latocha (2014)

Pechenick et al. (2014)

Florsheim et al. (2001)

Blanton and Marcus (2009)

Vis et al., (2003)

Beevers et al. (2012)

Roads in flat landscapes

Douven et al. (2012)

Douven and Buurman (2013)

Blanton and Marcus (2013)

Buchanan et al. (2013)

Kumar et al. (2014)

Trizzino (2015) 
Tab. 3

\section{Agriculture and soil erosion}

Drainage systems

Land abandonment
Martínez-Casasnovas and Sánchez-Bosch (2000)

Bielders et al. (2003)

Boardman et al. (2003, 2006)

Van Oost et al. (2006)

Boardman and Poesen (2006)

Knox (2006)

Doolittle (2006)

O'Connell et al. (2007)

Evrard et al. (2007)

Atapattu and Kodituwakku (2009)

Heitz et al. (2009)

Cerdà et al., (2009)

Boardman and Vandaele (2010)

Boardman (2010)

García-Ruiz and Lana-Renault (2011)

Florsheim et al. (2011)

Massa et al. (2012)

Tetzlaff et al. (2013)

Cerda et al. (2013)

Palmer and Smith (2013)

Merten and Minella (2013)

Dotterweich et al. (2013)

Dotterweich (2013)

Boardman (2013)

Lieskovský and Kenderessy (2014)

García-Ruiz et al. (2015)

Arnáez et al. (2015)

Dotterweich et al. (2015)

García-Ruiz (2010)

Arnaez et al. (2011)

García-Ruiz and Lana-Renault (2011)

García-Ruiz et al. (2013)

Debolini et al. (2013)

Tarolli et al. (2014)

Krause et al. (2007)

O'Connell et al. (2007)

Schilling and Helmers (2008)

Schilling et al. (2008)

Blann et al. (2009)

Wheater and Evans (2009)

Lenhart et al. (2012)

Sofia al. (2014c)

Schottler et al., (2014)

Schottler et al. (2014)

Kiss and Benyhe (2015) 
Tab. 4

\begin{tabular}{ll}
\hline \multirow{2}{*}{ Overview } & Tarolli (2014) \\
& Jones et al. (2014) \\
& Passalacqua et al., (2015) \\
& Wasklewicz and Scheinert (2016) \\
\hline \multirow{2}{*}{ Mining landscape } & Francioni et al. (2015) \\
& Chen et al. (2015) \\
& Hancock et al. (2015) \\
\hline \multirow{2}{*}{ Road networks } & Tarolli et al. (2013) \\
& Sherba et al. (2014) \\
& Sofia et al. (2015) \\
& Sofia and Tarolli (2015) \\
& Martínez-Casasnovas et al. (2013) \\
Agricultural landscapes & Tarolli et al. (2014) \\
& Sofia et al. (2014b) \\
& Diaz-Varela et al. (2014) \\
& Tarolli et al. (2015) \\
& Stöcker et al. (2015) \\
& Prosdocimi et al. (2015) \\
\hline
\end{tabular}


Fig.1
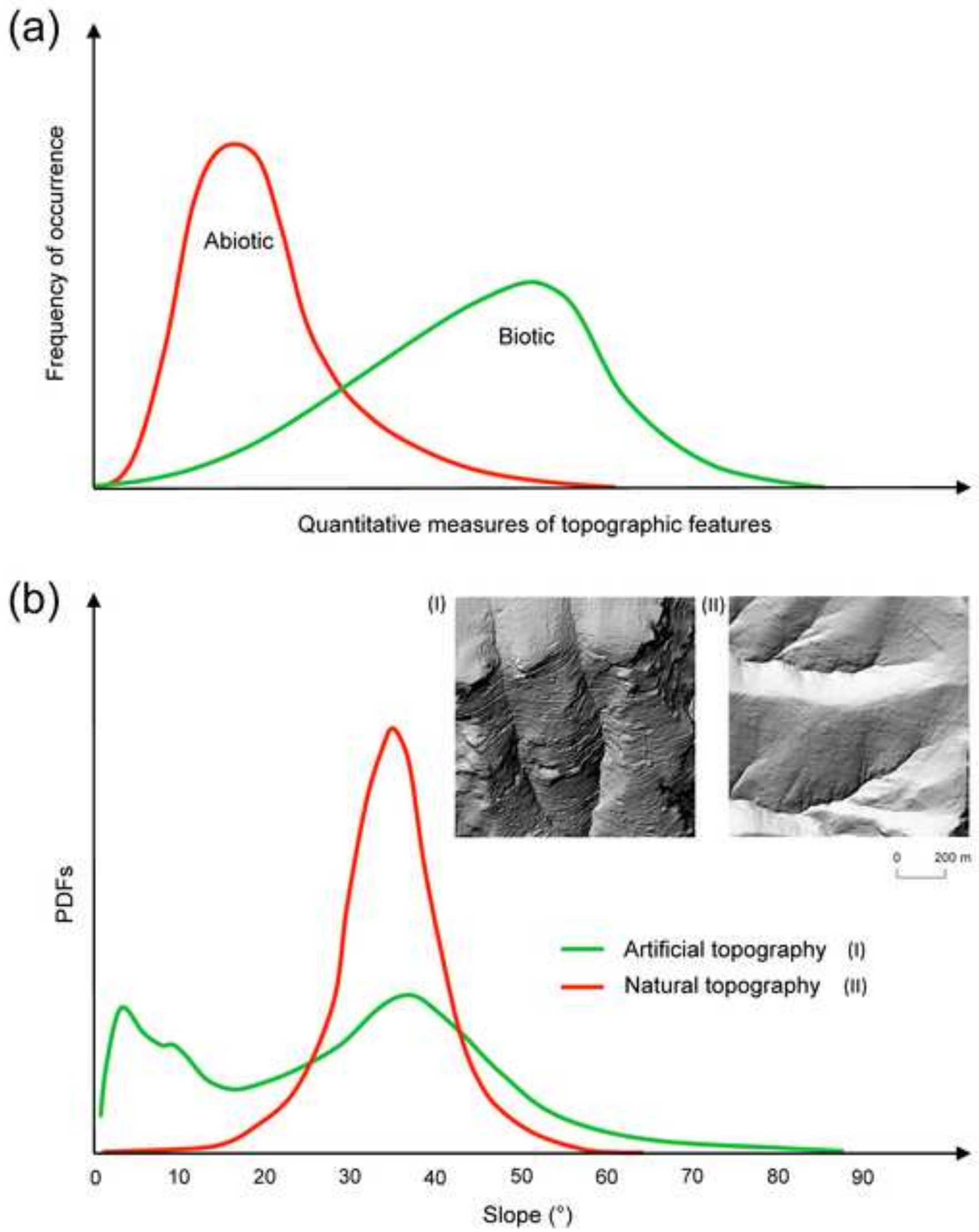

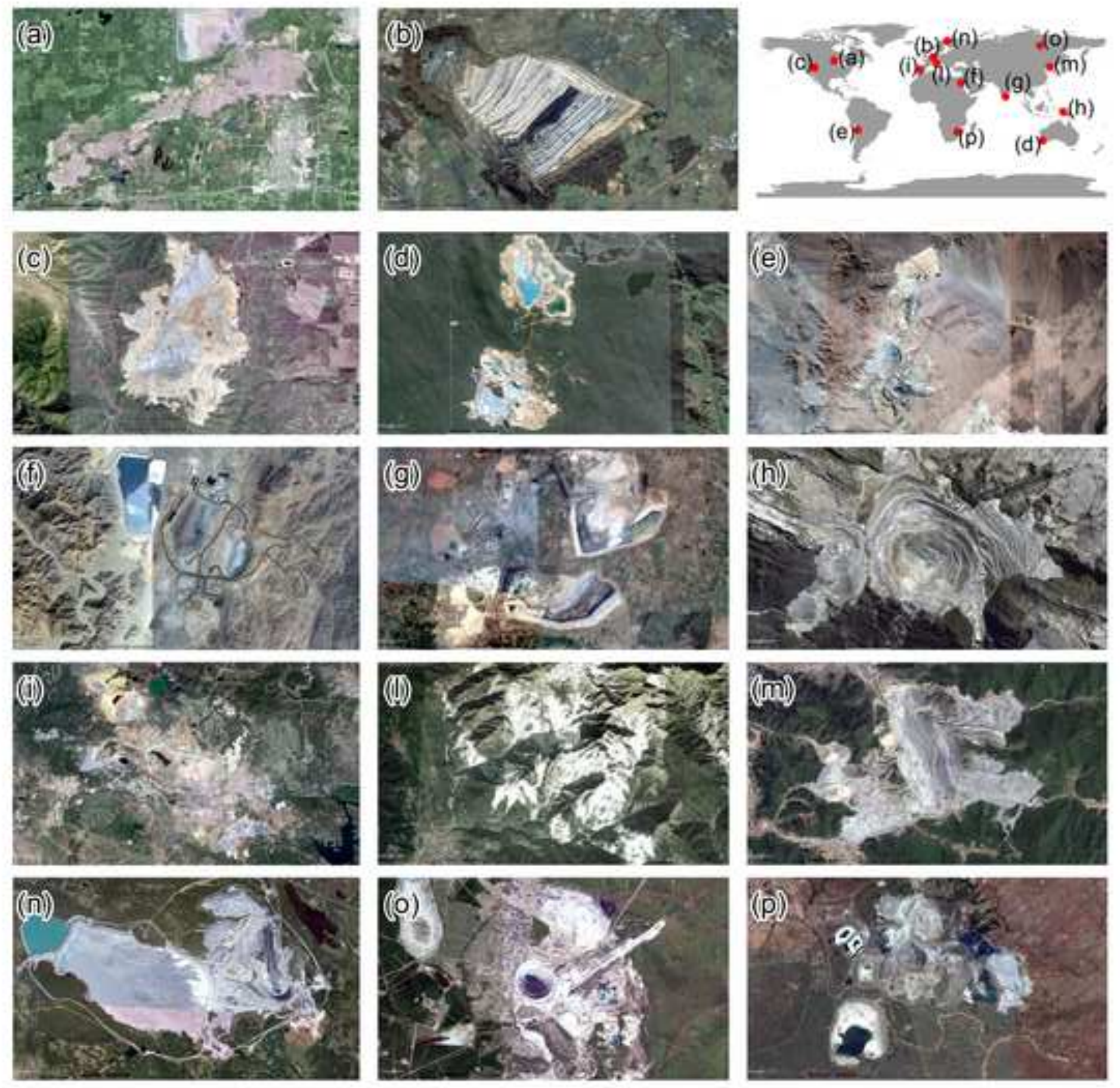

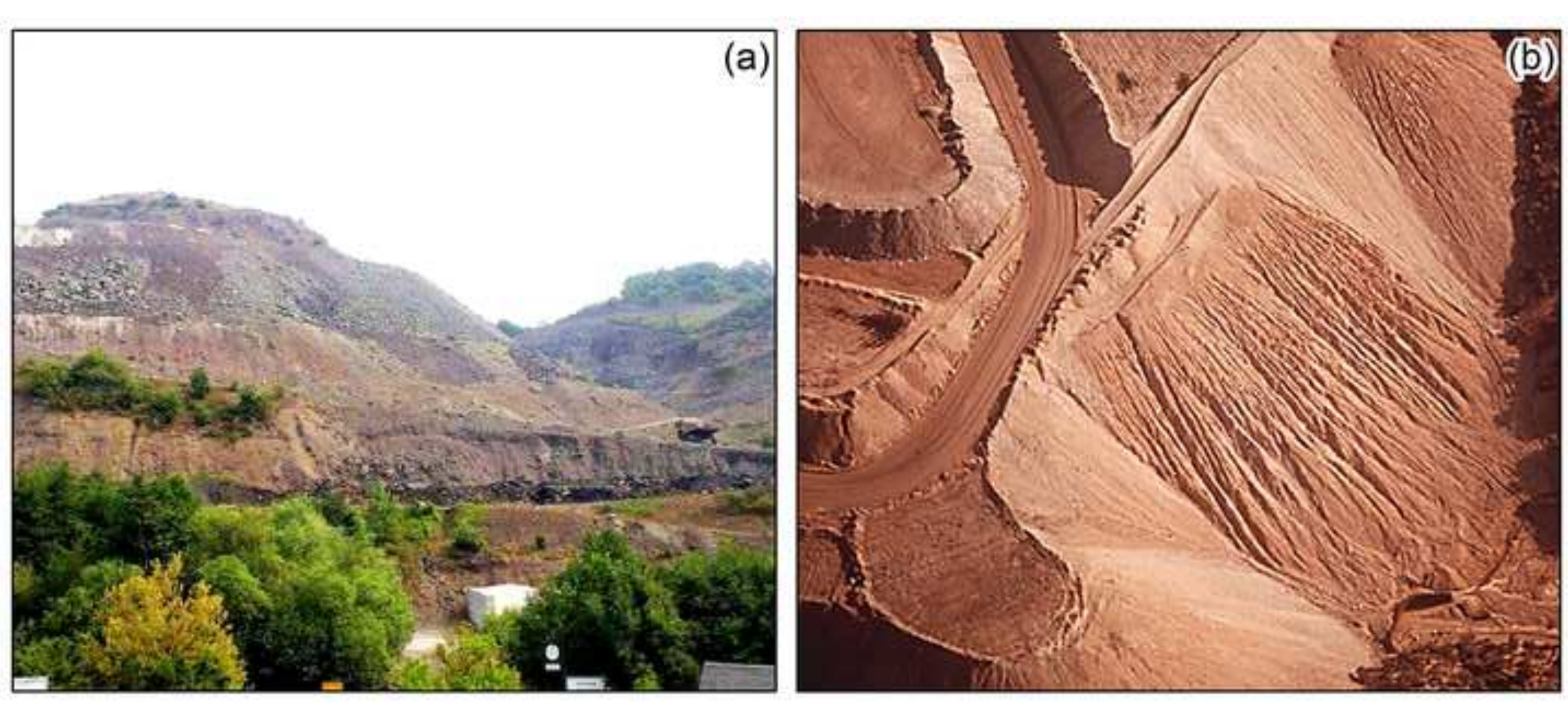


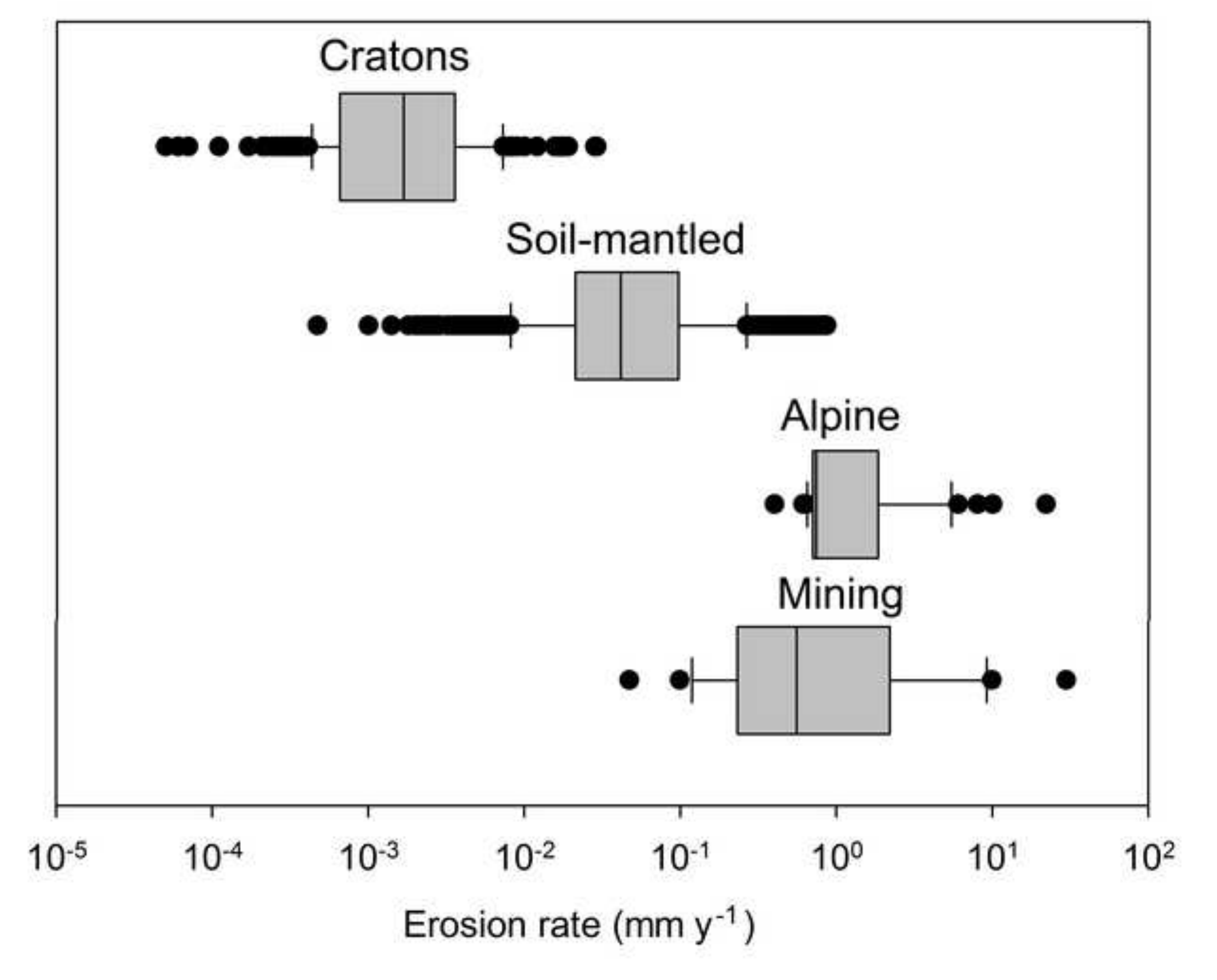

Erosion rate $\left(\mathrm{mm} \mathrm{y}^{-1}\right)$

Alpine

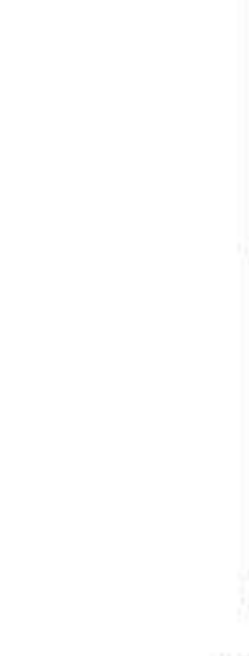

$10^{-5}$

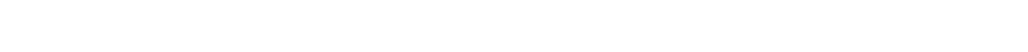

(

.

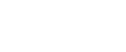

$\sqrt{2}+x^{2}$

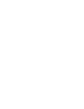

.

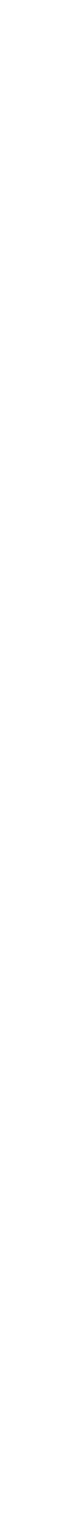



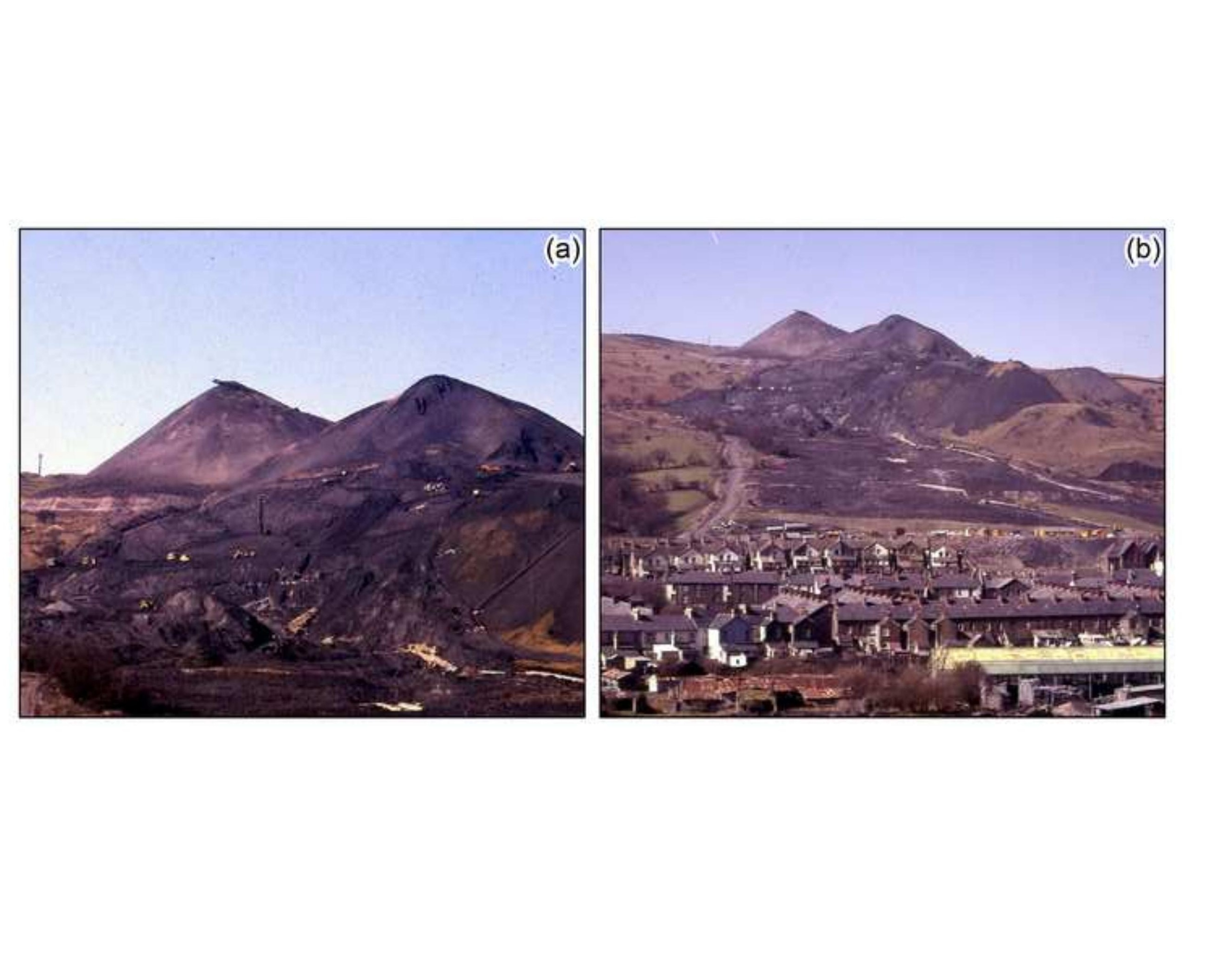

(b)

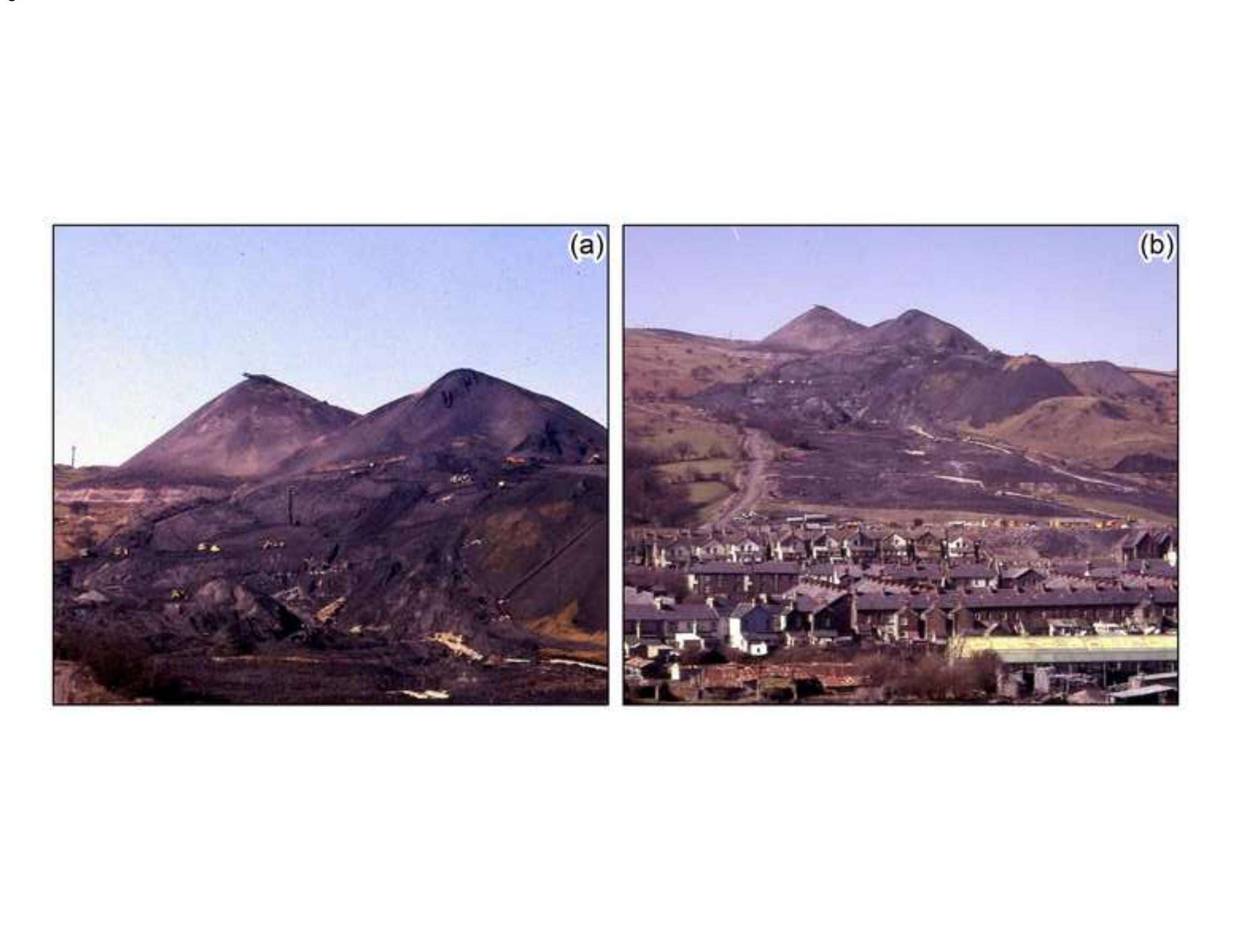

(
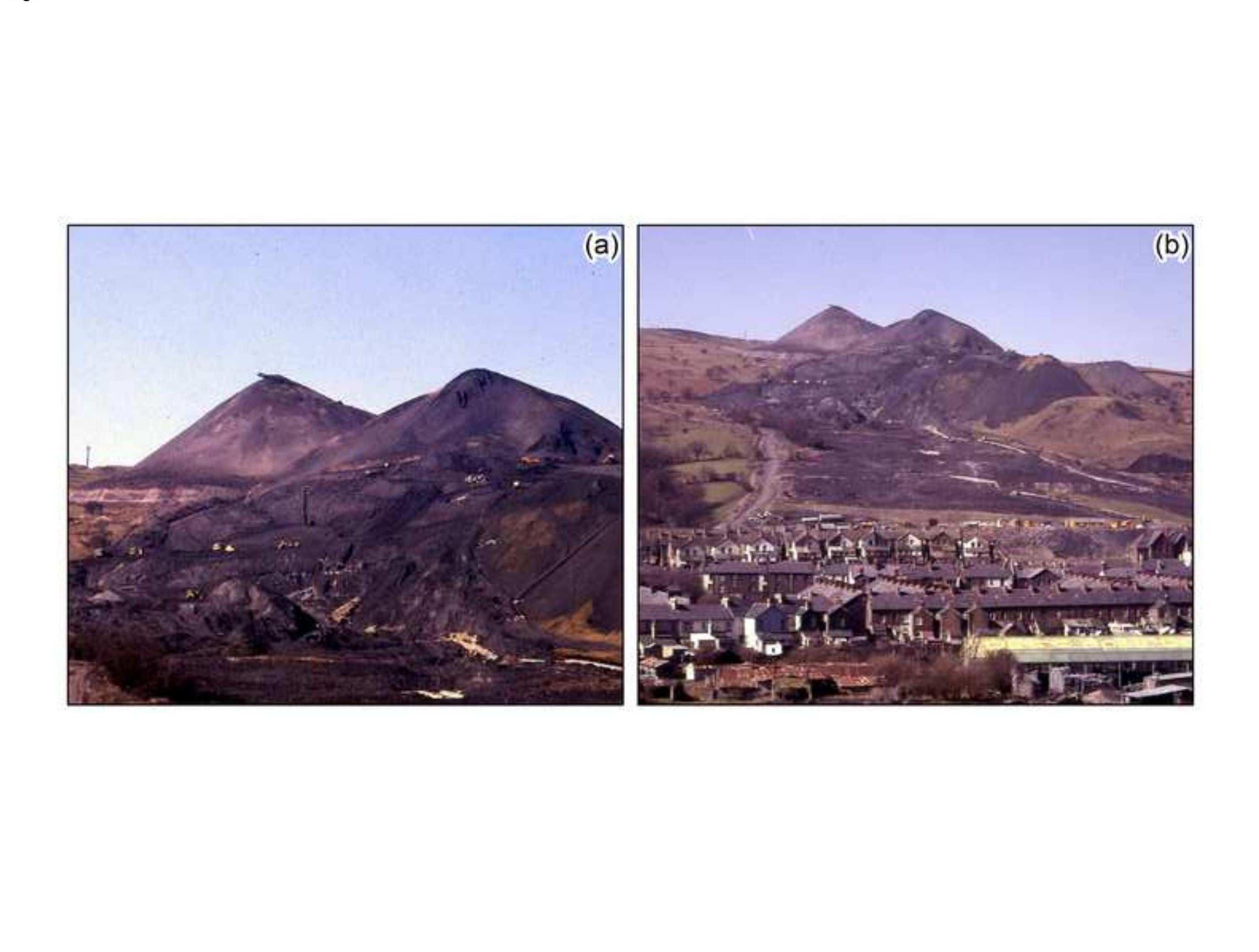

句



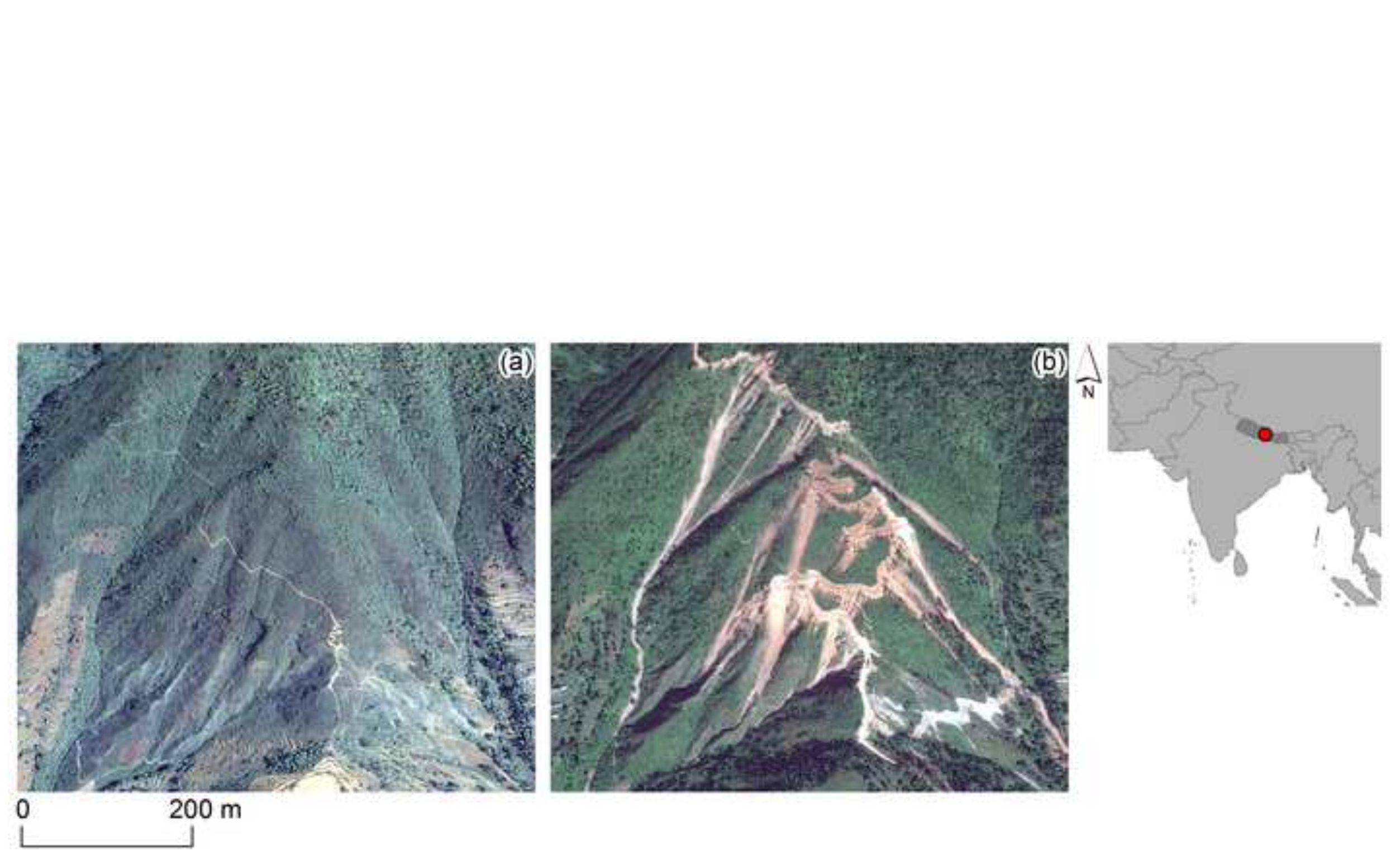
0 $200 \mathrm{~m}$

\lrcorner

$\mathrm{N}$

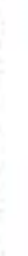$$
\text { ( }
$$
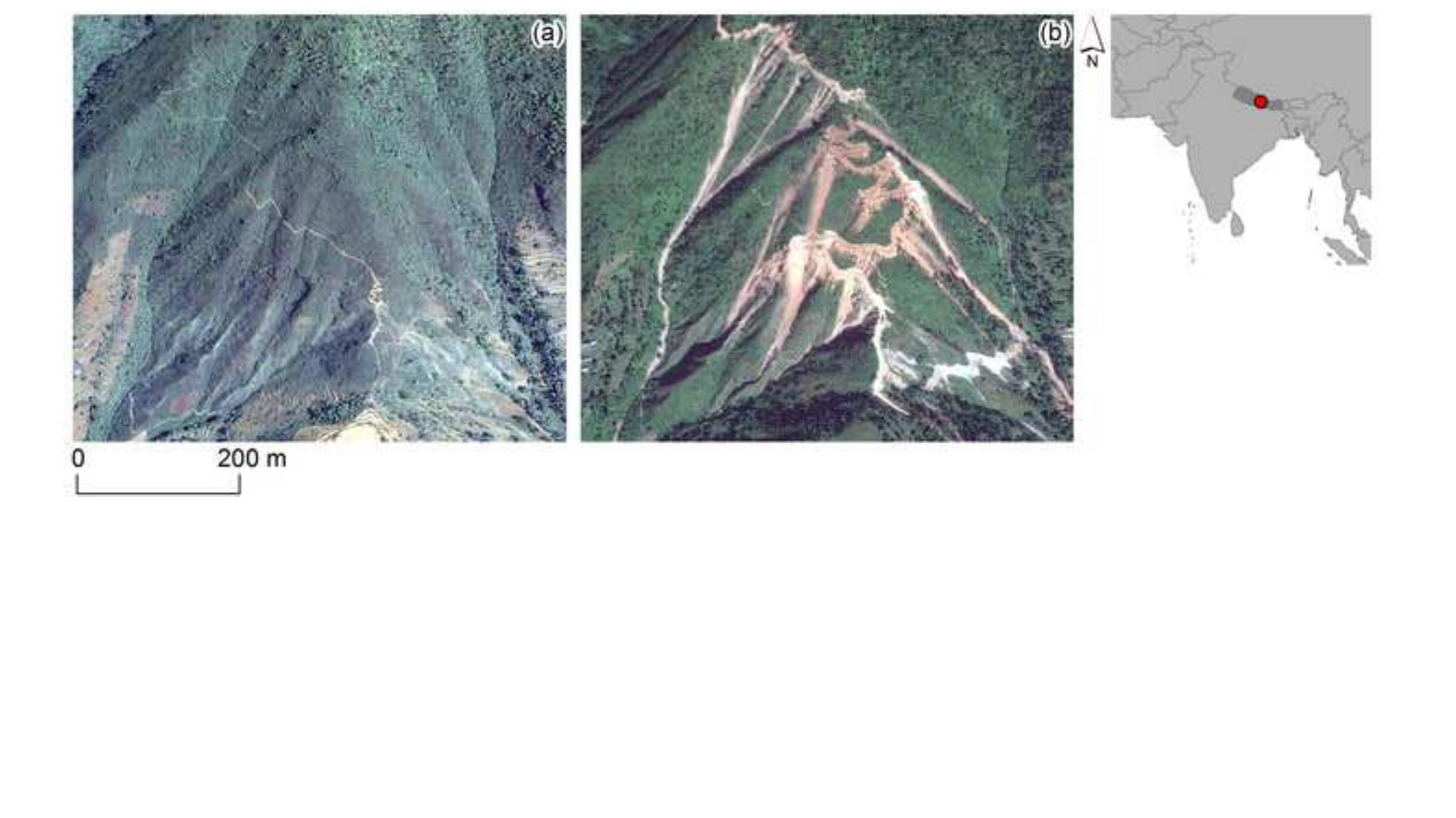

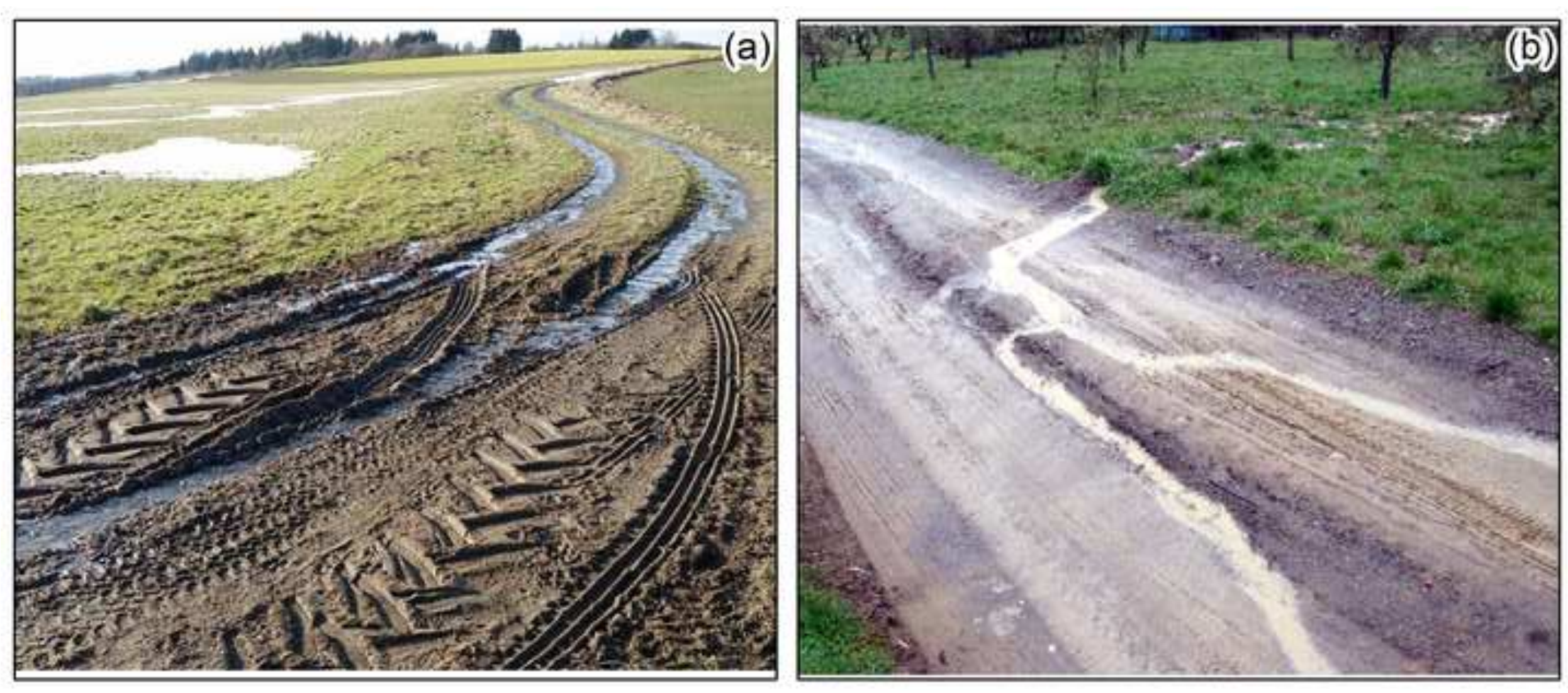

$$
\text { (5) }
$$

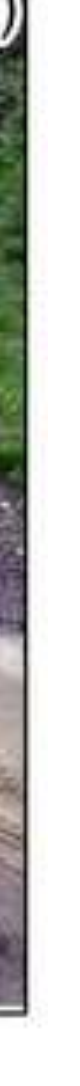



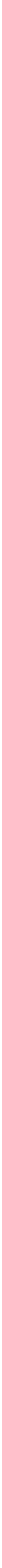

pop
pop 

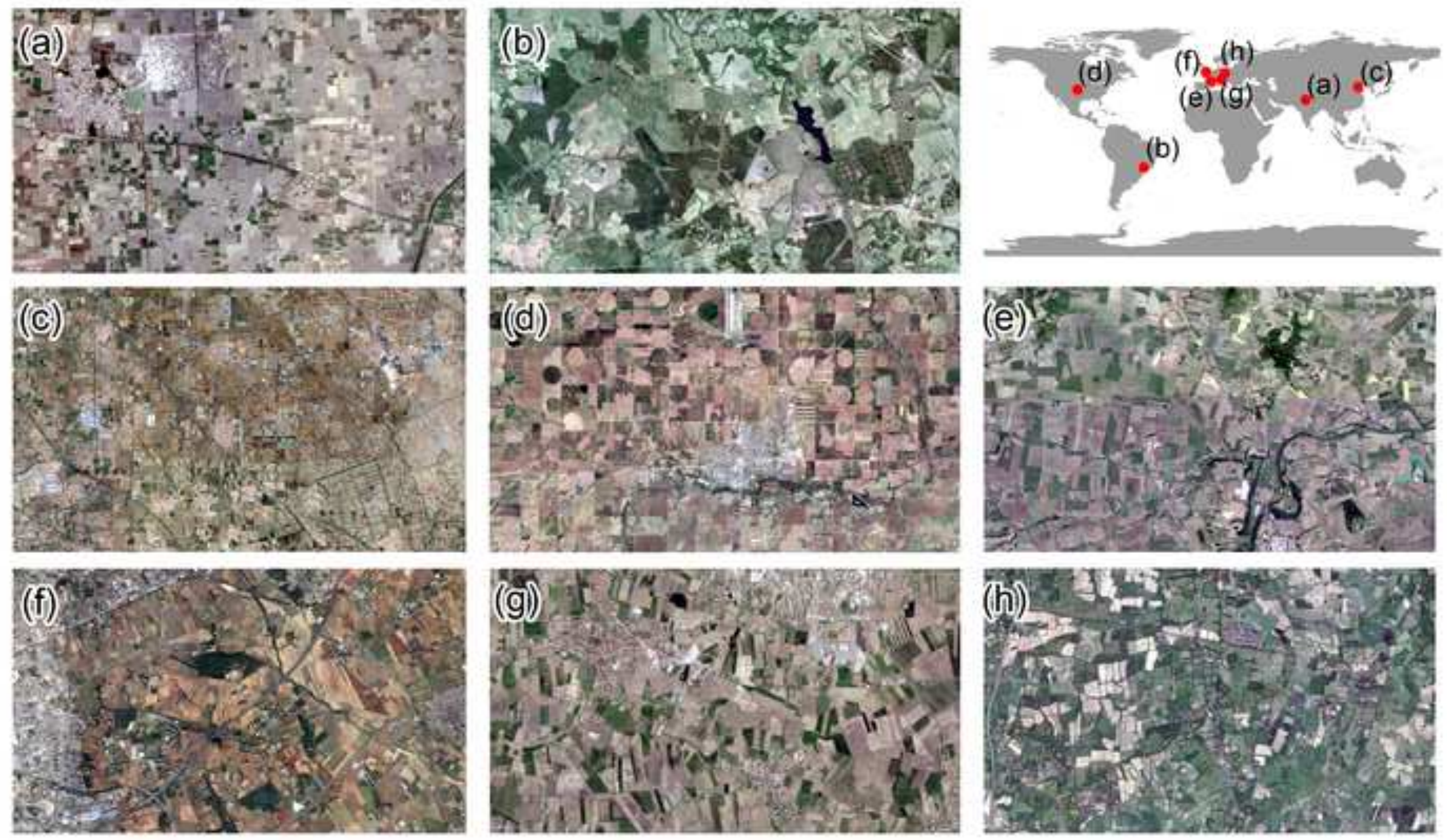


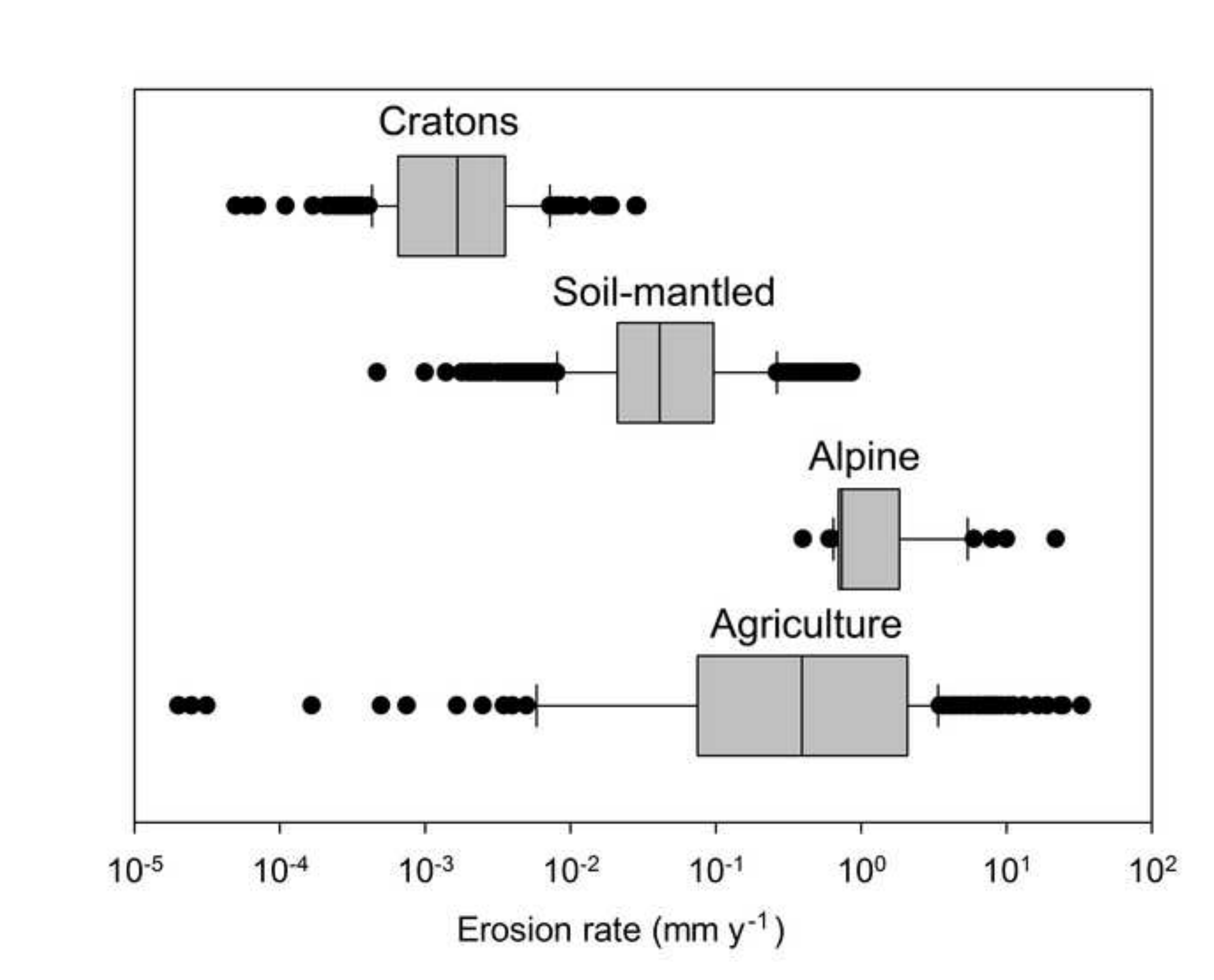




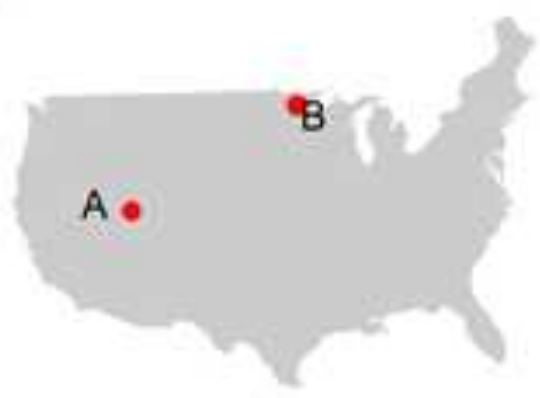

A

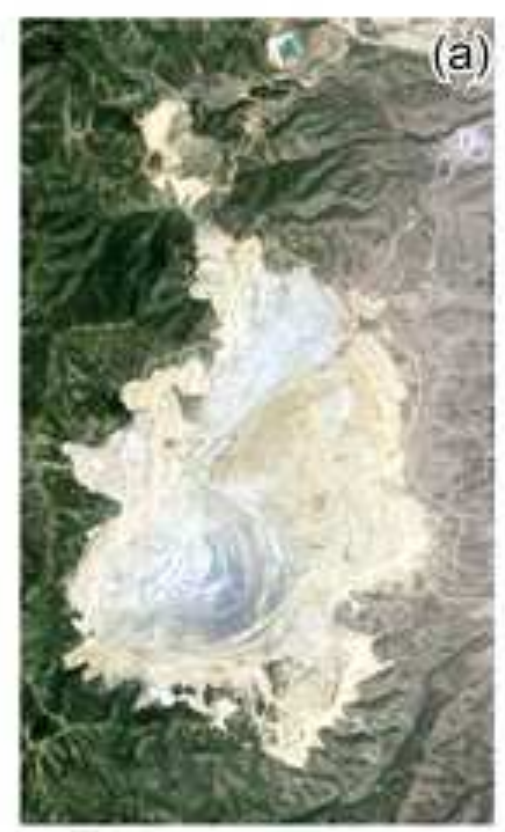

$01000 \mathrm{~m}$
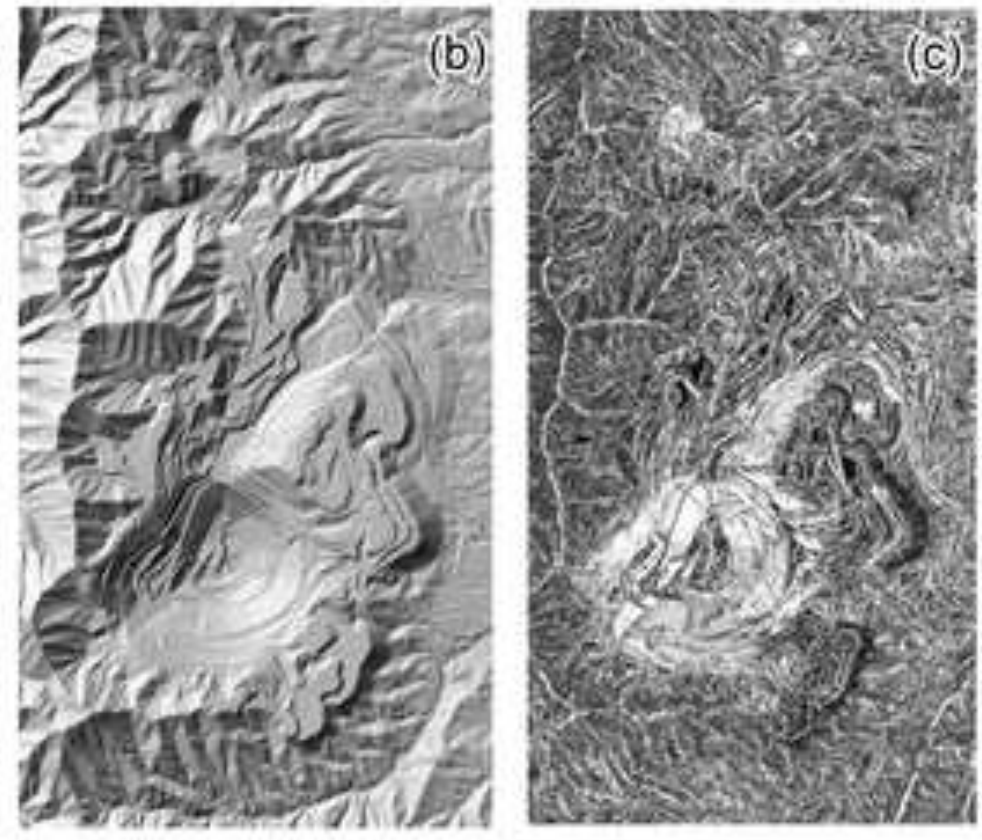

$\frac{1}{N}$

SLLAC (m)

e $<10$

E $10-20$

. $20-30$

$30-40$

ㄹ. 40.50

(1) $50-60$

$60-70$

$70-80$

80.90

90. 100

$\square 100 \cdot 110$

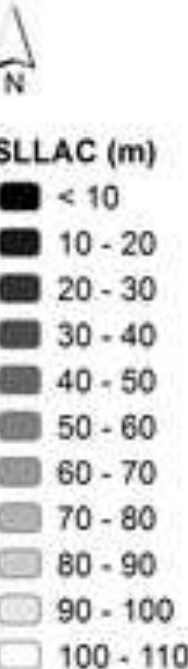

B

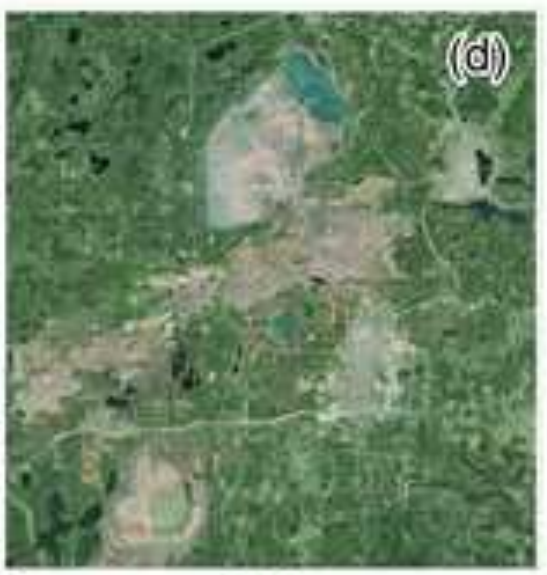

$10000 \mathrm{~m}$ 0

.
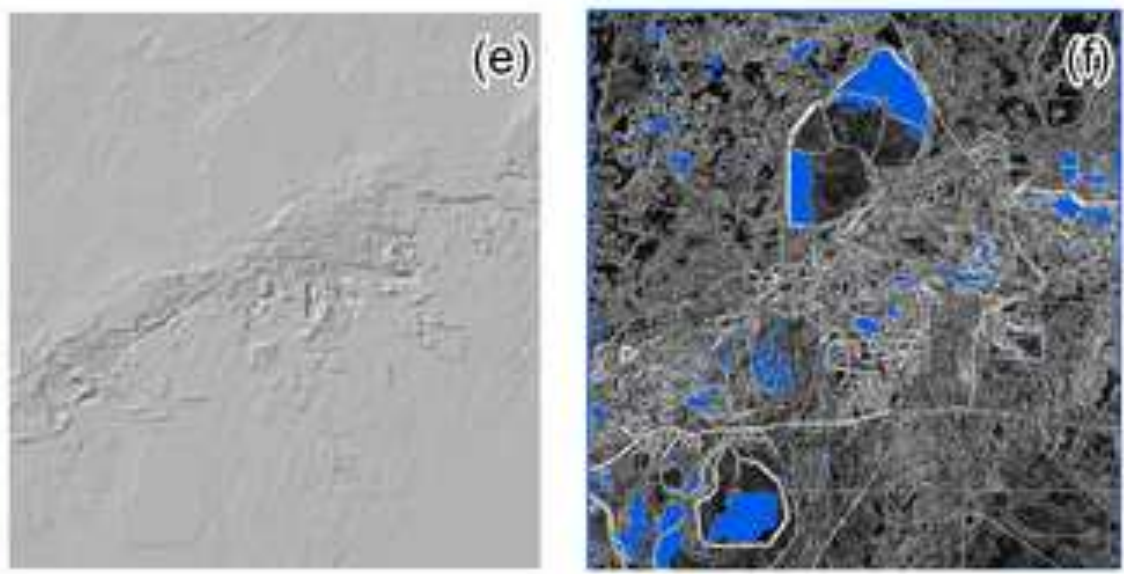
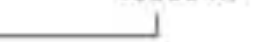

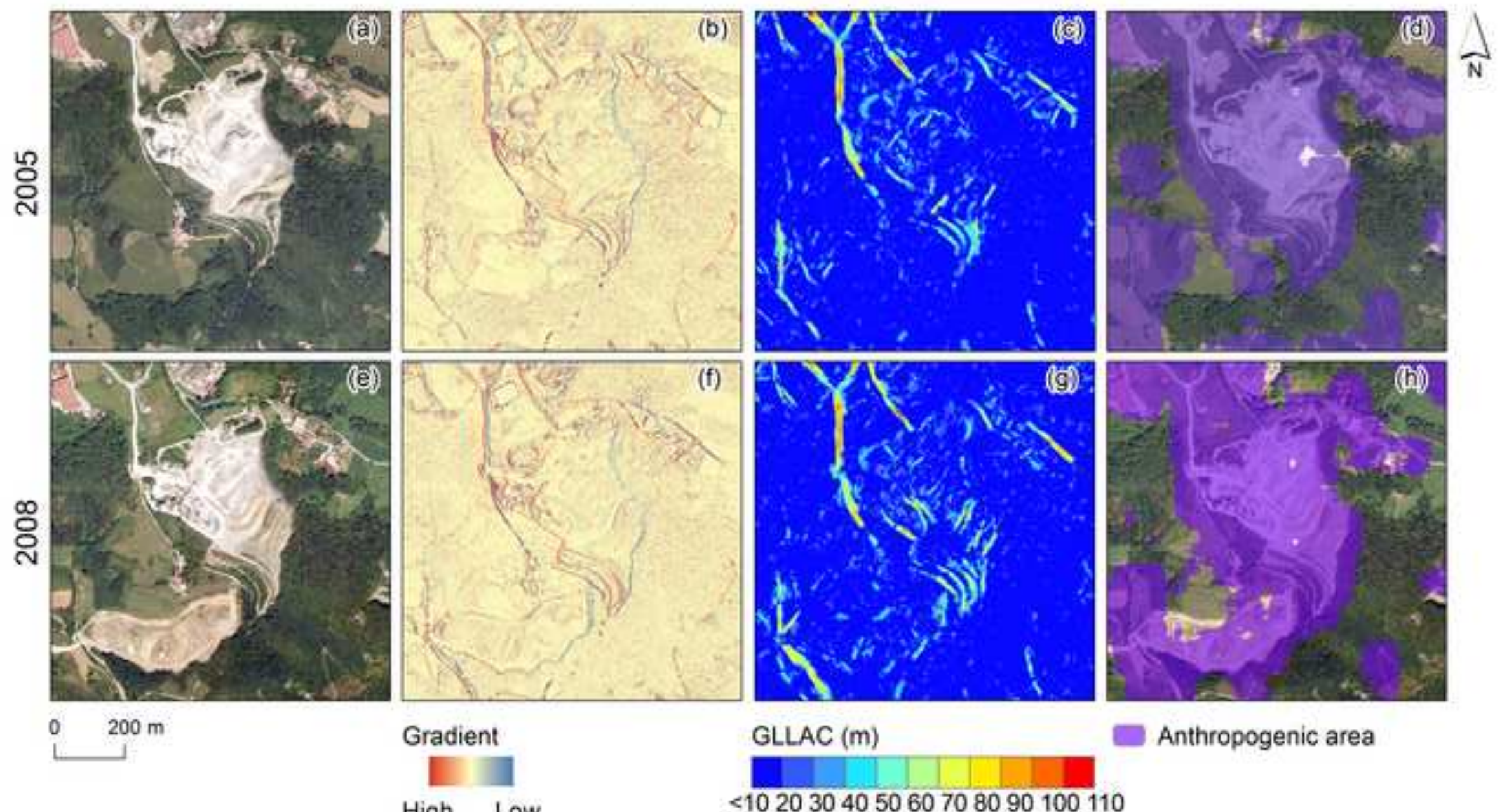

GLLAC (m)

Anthropogenic area

High Low

$<102030405060708090100110$ 


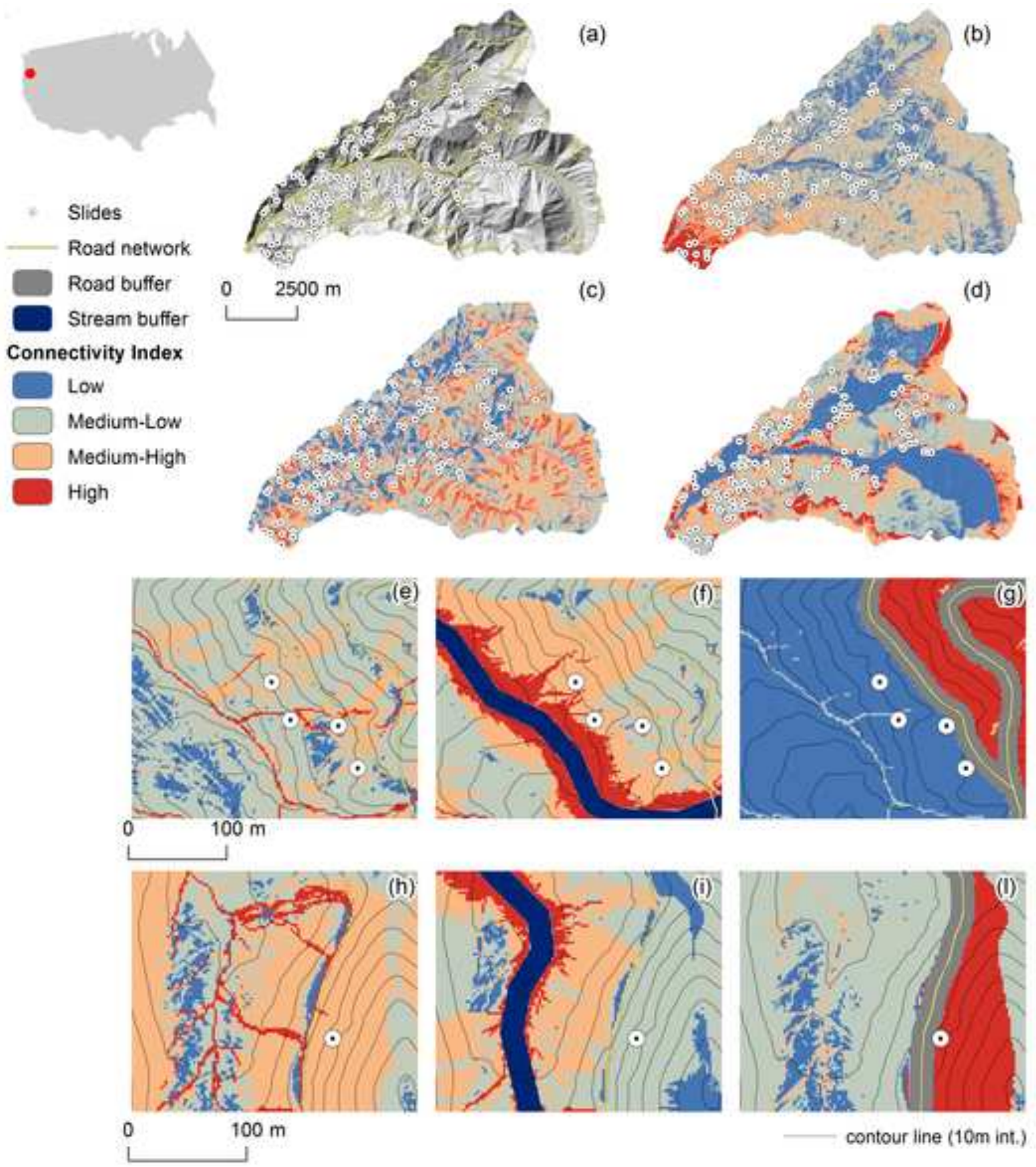



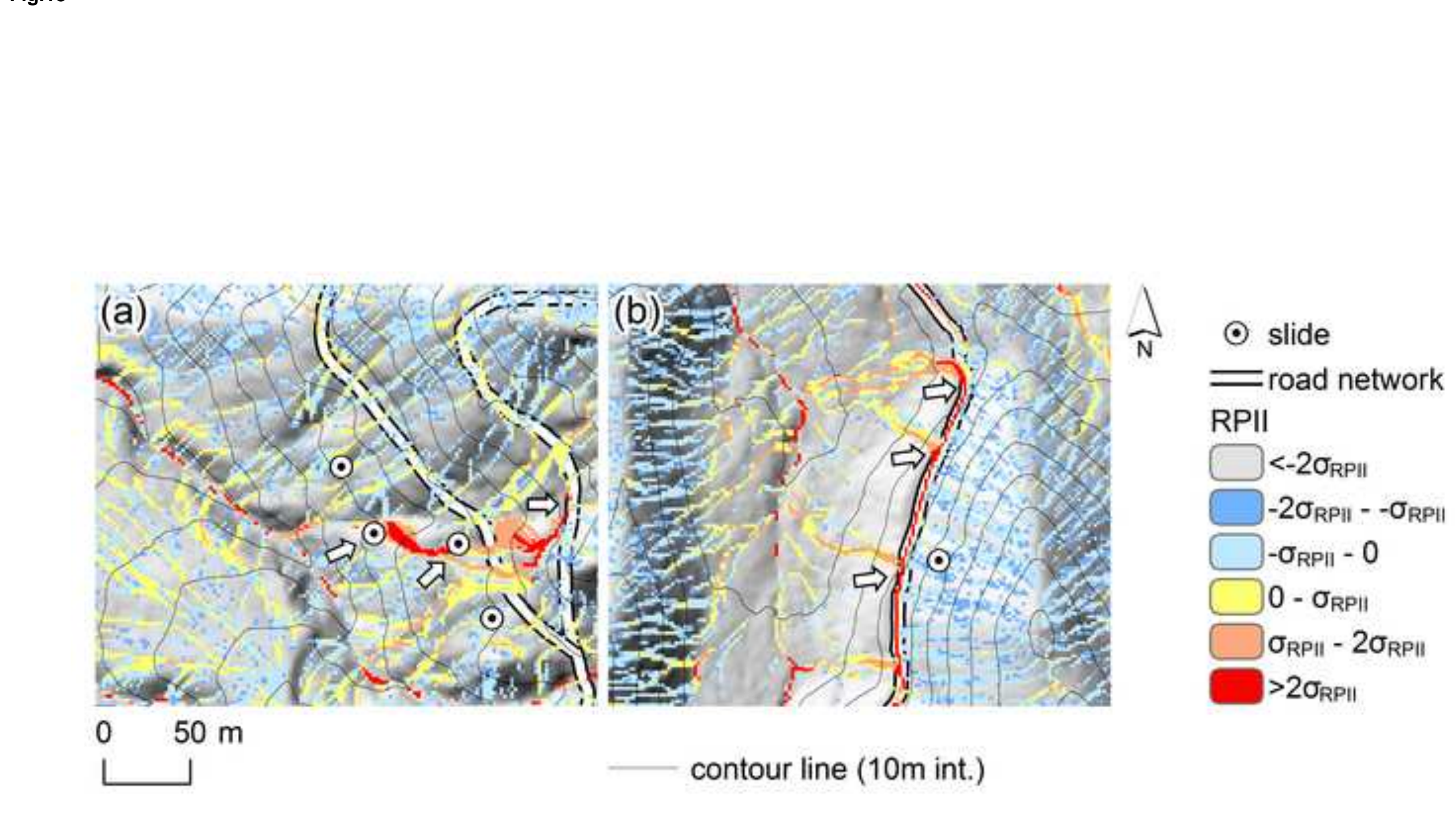
RPII

$\square-2 \sigma_{R P \|}$
$-2 \sigma_{R P \|}--\sigma_{R P \|}$
$-\sigma_{R P \|}-0$
$0-\sigma_{R P \|}$
$\sigma_{R P \| I}-2 \sigma_{R P \|}$
$>2 \sigma_{R P \|}$

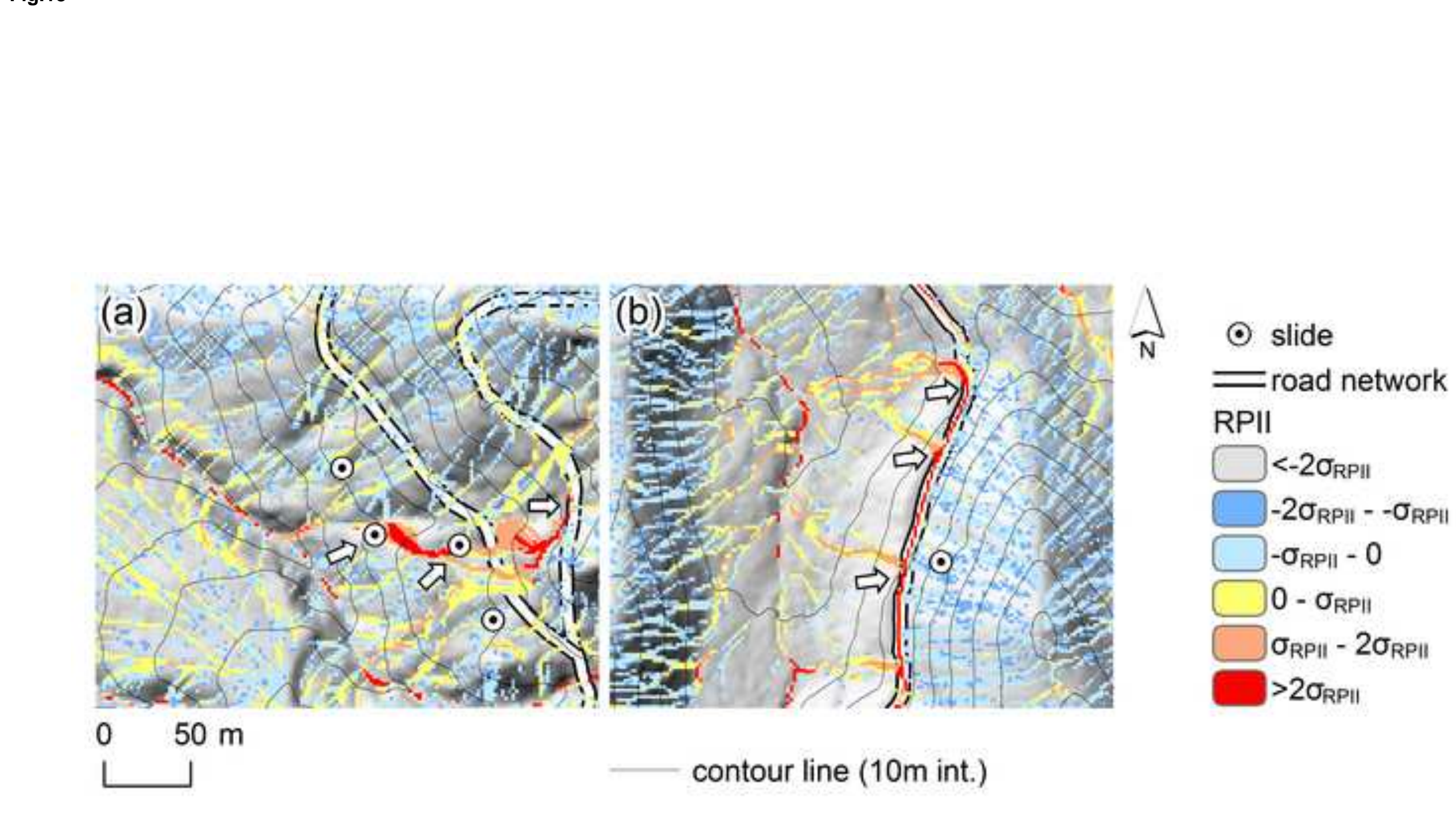

